\title{
Seed priming technology as a key strategy to increase crop plant production under adverse environmental conditions
}

\author{
Daniel Garciaa, , Shuo Zhaoa, Samiah Arifa, Yinglei Zhao ${ }^{\mathrm{b}}$, Lin Chau Mingc and Danfeng Huanga,**
}

a School of Agriculture and Biology, Shanghai Jiao Tong University, Shanghai, 200240, China

${ }^{\mathrm{b}}$ College of Bio Systems Engineering and Food Science, Zhejiang University, Hangzhou, 310058, China

cHorticulture Department, Faculty of Agronomic Sciences, São Paulo State University Julio de Mesquita Filho (UNESP), 18610307, Botucatu, Sao Paulo, Brazil

* Correspondence: authors. Tel.: +8613601682332. E-mail address: danielgarciafic@hotmail.com (D. Garcia); hdf@sjtu.edu.cn (D. Huang)

\begin{abstract}
Farmers and seed companies constantly require high-quality seeds with excellent agronomic performance. However, faced with environmental adversity, limited natural resources and increasing food demand around the globe, more attention has turned to improving crop plant production by implementing efficient strategies. Seed priming technology has shown promising biological improvements leading to suitable agronomic performance in crop plants under adverse environmental conditions. Seeds are subjected to controlled conditions that are conducive to complex physiological, biochemical, and molecular changes, conferring specific stress tolerance to subsequent germination and growth conditions. In this review paper, we aimed to study the recent approaches in the efficiency of hydropriming, osmopriming, chemopriming, hormopriming, nanopriming, matrix priming, biopriming, physical priming and hybrid priming procedures in the production of crop plants under environmental adversity, as well as their biological mechanism changes. All priming methods demonstrated relevant changes in the biological mechanism related to crop plant production by mitigating salinity effects, heavy metals, and flooding stress and enhancing chilling, heat, drought and phytopathogen tolerance. We strongly recommend that researchers combine multiple priming methods, known as hybrid priming, in their investigations to provide novel technologies and additional biological approaches to enhance the knowledge of crop plant science. Thus, the findings shed light on the use of seed priming technology as a key strategy to increase crop plant production under environmental adversity by acquiring stress tolerance and enhancing agronomic traits to meet the global food demand.
\end{abstract}

Keywords: stress tolerance; biological mechanisms; biotic/Abiotic stress; hybrid priming; high-quality seeds

\section{Introduction}

Faced with the increasing population and limited natural resources, climate change has imposed extra adverse conditions on crop plant production. This situation has worsened to the extent that food consumption has increased disproportionately to the population increasing in the last few years ${ }^{1}$. Moreover, it is predicted that by 2050, 
salinization consequences will affect $50 \%$ of arable lands in the world ${ }^{2}$. In terms of economic losses, environmental stressors have decreased crop production in developing countries, with USD 9.5 billion lost to diseases and pest infestation, USD 29 billion to drought, and USD 47 billion to other causes between 2005 and 2015, according to the $\mathrm{FAO}^{3}$. At the field level, during their lifespans, crop plants are exposed to several biotic and abiotic stressors such as temperature, sunlight, soil moisture, dissolved solids, atmospheric composition, phytopathogens and pests. Consequently, these factors reduce crop production, affect economic stability and threaten global food security (Fig. 1).

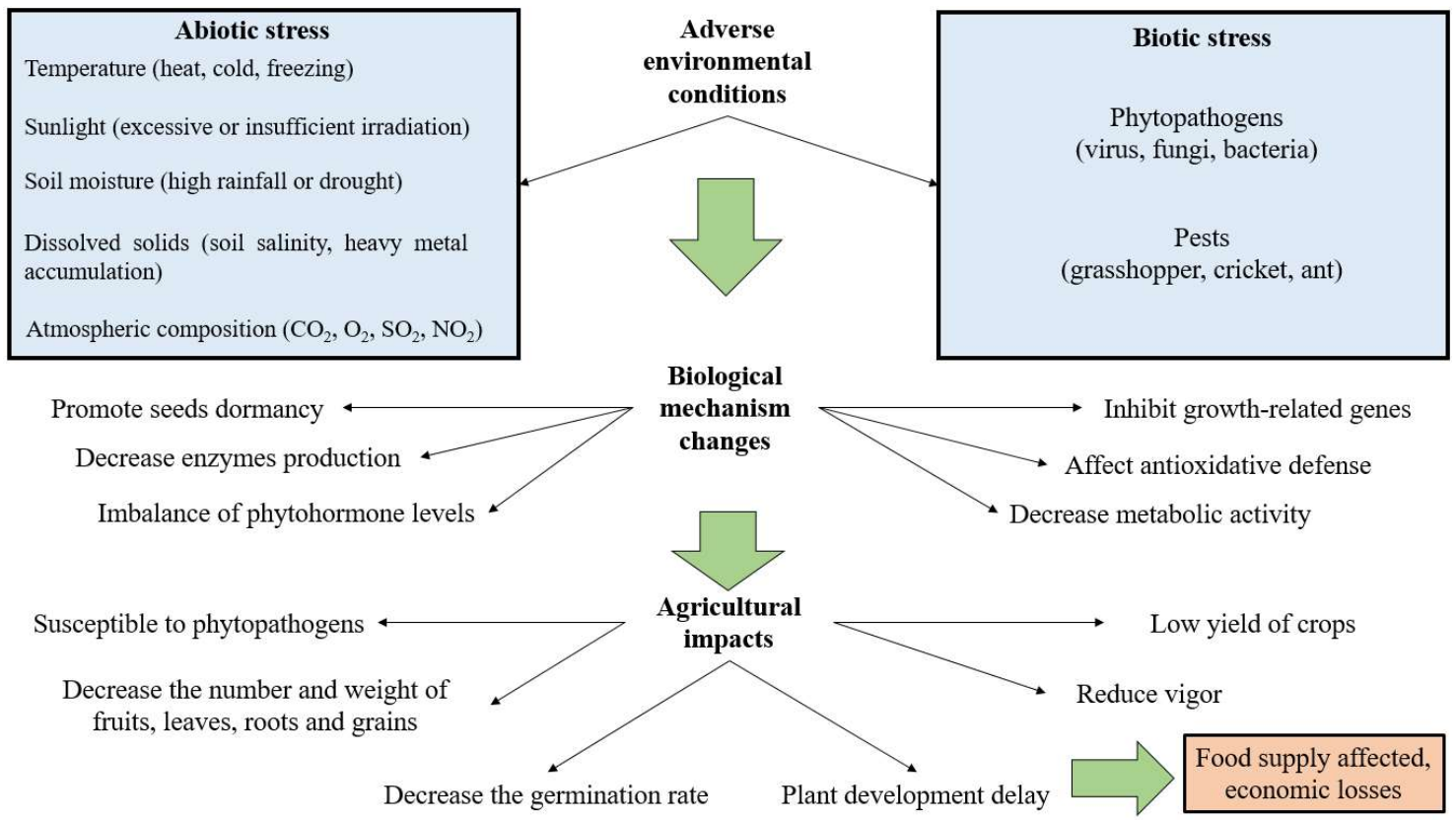

Figure 1. Adverse environmental conditions induce negative changes in biological mechanism of crops, affecting crop production, food supply and economic stability.

Among the several biological changes in crop plants that experience unsuitable environmental conditions, seed dormancy is considered one of the most common physiological consequences that significantly decrease crop production ${ }^{4}$. Dormancy is characterized by the inhibition of germination while waiting for favorable conditions ${ }^{5}$. In terms of phytohormones, germination and dormancy are controlled by the balance of hormone ratios, mainly ABA (abscisic acid) and GAs (gibberellins) ${ }^{4,5}$. These hormones are stimulated by specific growthrelated genes, which in turn are down/upregulated mainly by environmental factors 6,7 .

In an attempt to mitigate the negative impacts of biotic/abiotic stressors on crop plant production and increase agronomic traits, numerous studies have focused on static farming management, such as watering volume and frequency ${ }^{8}$, fertilizer and pesticide amounts ${ }^{9}$, and other techniques, including the use of resistant varieties ${ }^{10}$. Thus, among the several technologies available to increase crop production, one of the most feasible, low-risk and cost-effective is seed priming ${ }^{11-16}$. Seed priming is defined as a 'pregermination' metabolism inducing several physiological, biochemical, and molecular changes to activate stress- 
responsive genes associated with germination ${ }^{17}$, in which the seed prepares for imminent environmental stress. Stress tolerance acquired through priming treatments has been suggested to possibly be associated with "priming memory". According to Chen and Arora11, "priming memory" invokes stress tolerance in seeds depending on the conditions that were previously imposed on the seeds. In other words, seeds retain the preceding stress memory after the priming procedures, which may aid in the attainment of tolerance to subsequent stresses (Fig. 2).

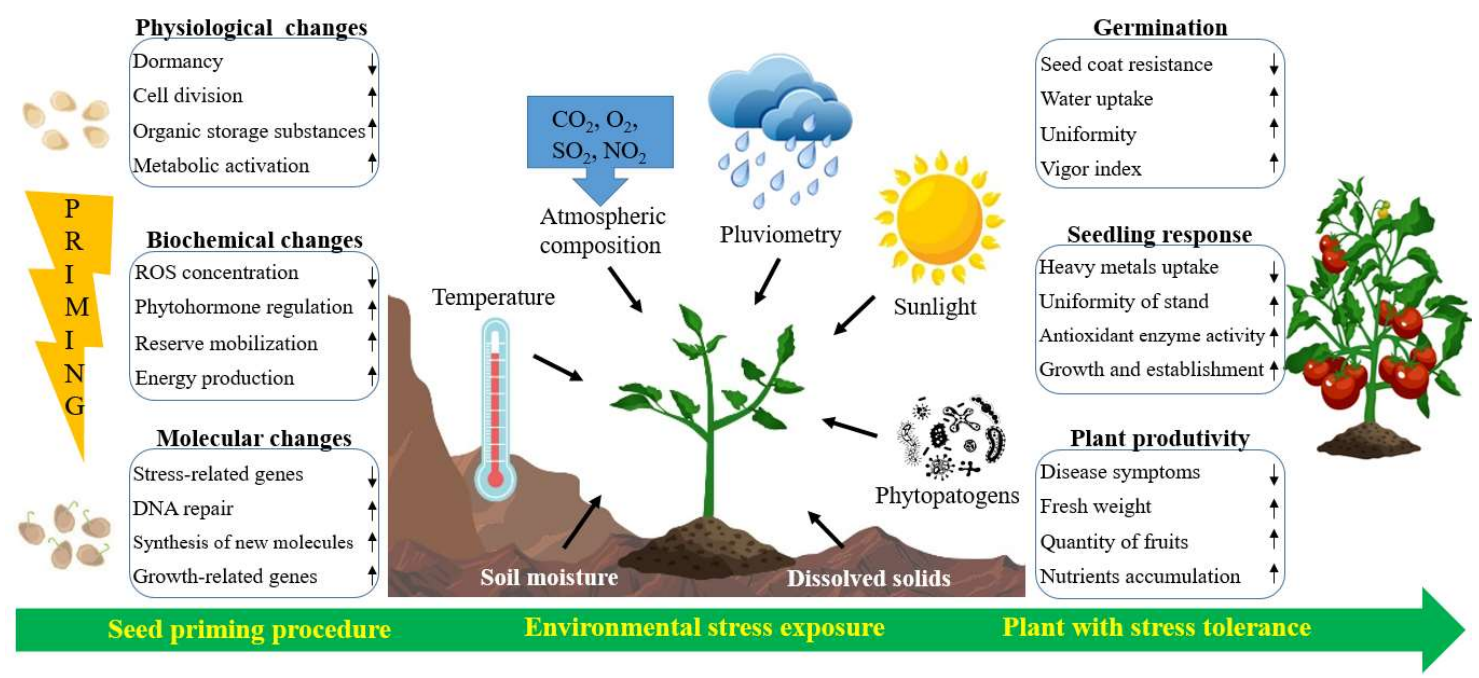

Figure 2. Schematic representation summarizing the mechanism underlying environmental stress tolerance acquired by primed seeds.

Seed priming technologies are emerging as a potential and promising method to increase crop production efficiently under unsuitable environmental conditions $s^{13,16,18-21}$. Seed priming methods are capable of improving the morphophysiological pattern, regulating phytohormones, reprogramming gene expression, and inducing the metabolism of important enzymes $13,22,23$. Germination occurs in three phases after the dry seeds are sown: (I) imbibition, (II) 'pregermination', and (III) emergence ${ }^{14,24}$. The procedure of seed priming is known to trigger 'pregermination' without radicle emergence. Different antioxidants, such as catalase (CAT), ascorbate peroxidase $(A P X)$, superoxide dismutase $(S O D)$, and peroxidase $(P O D)$, are commonly triggered during seed priming procedures. These antioxidants protect cellular membranes against the harmful effects of reactive oxygen species (ROS) and help mitigate environmental stressors and improve seed germination and seedling growth ${ }^{24,25}$ (Fig. 3). 


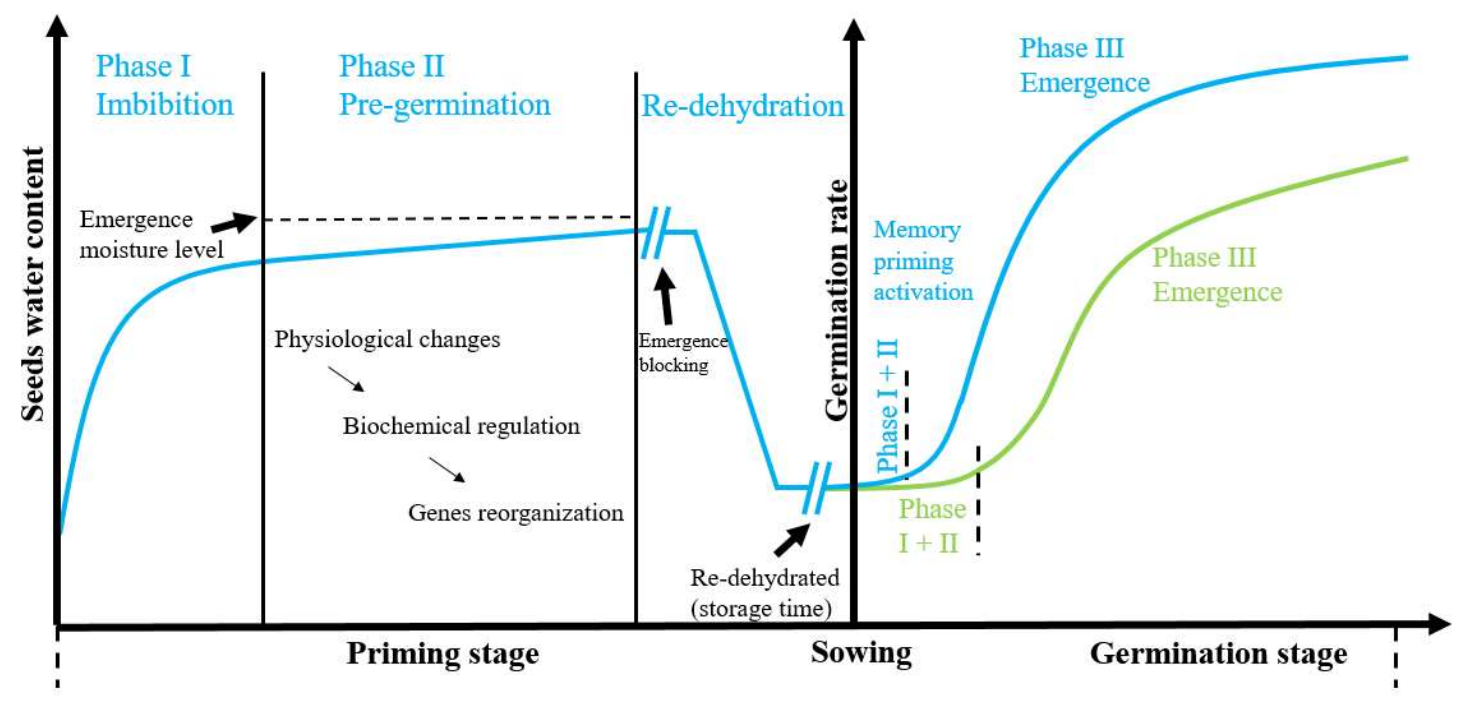

Unprimed seeds

Primed seeds

Figure 3. Schematic illustration of the seed priming process and comparison to the subsequent germination between unprimed seeds and primed seeds ${ }^{13,14}$. During phase I (imbibition), controlled water uptake allows the synthesis of protein and induces respiratory activities through messenger ribonucleic acid (mRNA). Phase II (pregermination) is related to several physiological, biochemical and molecular activities related to germination, such as protein synthesis, metabolic processes, mitochondrial synthesis, alterations in soluble sugars, and repair processes, but the emergence of radicles is prevented. Re-dehydration is necessary when the final sowing is postponed, in the case of seed companies. In primed seeds, phase III (emergence) is identified by memory priming activation, which results in better seed emergence performance, while unprimed seeds spend time performing phases I and II longer ${ }^{14}$.

Priming technology has been appreciated by farmers and seed companies due to its great agronomic performance with a wide range of crop plants ${ }^{13,16,24,26}$. Several investigations have demonstrated the advantages of seed priming procedures in crop plant production ${ }^{13,16,18-21}$, and reports of the negative effects of seed priming on agriculture remain scarce ${ }^{27}$. Considering the increasing food demand, limited natural resources and climatic change, the development of agricultural strategies is urgent to produce food efficiently ${ }^{16,19,28-30}$. In this context, the aim of this study is to summarize some of the main seed priming technologies: hydropriming, osmopriming, chemopriming, hormopriming, nanopriming, matrix priming, biopriming, physical priming and hybrid priming, referencing efficiency in the production of crop plants under adverse environmental conditions. The study also provides updated progress on seed priming technology as well as the agronomical potential of physiological, biochemical, and molecular approaches.

\section{Seed priming technologies}

The current study presents a wide range of evidence on the use of seed priming methods in crop plant production under adverse environmental conditions. In addition, a synopsis of several investigations on the biological effects of seed priming technology subjected to stress conditions and the impact on crop plant production is listed in Table 1. 


\subsection{Hydropriming}

Hydropriming, an ecofriendly, feasible, agronomically efficient, and cost-effective procedure to overcome many environmental stress conditions, allows suitable germination and seedling growth in Lupinus angustifolius L. ${ }^{31}$, Oryza sativa ${ }^{32}$, and Helianthus annuus L. ${ }^{33}$. Hydropriming is a simple method that involves soaking the seeds in pure water for a particular period at a controlled temperature under dark or light conditions ${ }^{14}$. A previous investigation reported the potential of hydropriming to enhance tolerance to low-temperature conditions in $L$. angustifolius ${ }^{31}$. The study investigated the impact of low temperature $(7$ ${ }^{\circ} \mathrm{C}$ ) on the physiological and biochemical changes during germination under the influence of the hydropriming method $\left(3 \mathrm{~h}\right.$ at $\left.20^{\circ} \mathrm{C}\right)$. The effectiveness of hydropriming in protecting seeds against cold damage during germination was confirmed due to reduced cell membrane permeability, amylolysis activity, and regulation of ABA content.

Hydropriming is widely used by seed companies to overcome irregular seed germination and stand establishment caused by unfavorable environmental conditions, such as drought, saline soils and heavy metal accumulation ${ }^{19,34}$. These stressors affect cell division and elongation, reduce nutrient uptake and translocation, and decrease tissue water status and photosynthesis, which consequently causes a reduction in enzymatic activity and overproduction of $\operatorname{ROS}^{35}$. To protect the cells from damage, plants activate a self-defense mechanism that controls ROS activities, such as $\mathrm{H}_{2} \mathrm{O}_{2}{ }^{36}$. Forti et al. ${ }^{34}$ promoted better seed germination and seedling establishment of Medicago truncatula in soil contaminated with heavy metals via the seed hydropriming method. The study successfully upregulated genes involved in DNA repair, such as OGG1 (8-oxoguanine glycosylase) and FPG (formamidopopyrimidine-DNA glycosylase) genes, and antioxidant activities ( $S O D$ and $A P X)$.

Anaerobic conditions during germination and seedling growth normally lead to poor establishment and low crop yield. Mondal et al. ${ }^{32}$ investigated the responses of hydropriming to the growth index and physiological processes of rice genotypes during germination and seedling growth under anaerobic conditions. Hydropriming significantly enhanced the emergence and seedling growth of rice in flooded soils. According to the study, hydropriming treatment was able to improve the breakdown of stored carbohydrates by enhancing the enzymatic activities of starch catabolic enzymes and maintaining lower malondialdehyde (MDA) concentrations, as supported by other investigations ${ }^{37}$.

\subsection{Osmopriming}

Routinely used by seed companies to enhance the vigor of seeds, osmopriming techniques have shown promising germination and plant growth performance ${ }^{38,39}$ under several adverse environmental conditions, such as chilling ${ }^{40}$, salinity ${ }^{41,42}$ and drought ${ }^{12}$. In this method, seeds are immersed in an osmotic solution with low water potential $(\psi)$ through the use of polyethylene glycol (PEG), mannitol, sorbitol, glycerol, or inorganic substances, such as $\mathrm{NaCl}, \mathrm{KCl}, \mathrm{K}_{2} \mathrm{SiO}_{3}, \mathrm{KNO}_{3}, \mathrm{MgSO}_{4}$, and $\mathrm{CaCl}_{2}$. This immersion allows the seeds to absorb water slowly, thereby culminating in less cellular damage. Tabassum et al. ${ }^{43}$ studied osmopriming (with $1.5 \% \mathrm{CaCl}_{2}$ solution) in the production of wheat (Triticum aestivum L.) under drought stress. The results revealed promising crop plant enhancement in comparison with hydropriming 
treatments regarding osmolyte accumulation, tissue water, leaf area, and yield. The positive plant responses were better with osmopriming due to a considerable decrease in lipid peroxidation and acquired drought tolerance. These results are in agreement with Chen and Arora ${ }^{44}$, who discussed that the stress tolerance acquired by osmopriming is, in part, related to the gradual accumulation of proteins, such as dehydrins (DHNs), usually reported to protect against cellular dehydration, and a more robust antioxidant system in relation to the activation of pregerminative metabolism. DHNs (group 2 LEA proteins) are watersoluble lipid vesicle-associated proteins involved in the adaptive responses of plants to environmental stress tolerance ${ }^{45}$. Later, Chen et al. ${ }^{46}$ successfully improved chilling and desiccation stress tolerance in Spinacia oleracea L. cv. Bloomsdale by osmopriming seeds. In this study, the authors associated stress tolerance with the accumulation of DHN-like proteins in spinach seeds, since they exclusively accumulated during the early phase of osmopriming in response to environmental stressors.

Soil salinity is another adverse condition that causes losses for crop plant production, especially in arid and semiarid regions ${ }^{42}$. Soil salinity becomes more extensive yearly, particularly as a result of inappropriate agronomic management $\mathrm{t}^{47,48}$. Salinity stress conditions cause increasing osmotic pressure, ion uptake imbalanced, and oxidative stress in sorghum, hence affecting the early growth stages and decreasing crop production ${ }^{49}$. Recently, wheat seeds osmoprimed with potassium silicate $\left(\mathrm{K}_{2} \mathrm{SiO}_{3}\right)$ was reported to be the most effective agent to relieve the negative impact of salinity stress during germination and plant growth ${ }^{50}$. Kubala et al. ${ }^{41}$ detected improvements in the germination and seedling growth of Brassica napus primed with polyethylene glycol (-1.2 $\mathrm{MPa}$ ) under salinity stress $(\mathrm{NaCl}: 100 \mathrm{mM})$. According to the study, the improvement of germination performance and seedling establishment in osmoprimed treatments was due to increased P5CSA gene expression and decreased $P D H$ gene expression associated with proline accumulation and $\mathrm{H}_{2} \mathrm{O}_{2}$ concentrations. Further understanding of molecular markers is of interest for providing suitable protocols for seed priming programs for each plant species and local environmental constraints. Thus, this aspect is rather important because such molecular indicators linked with biological mechanism changes allow the prediction of seed quality and may provide further knowledge to support future studies and provide assistance to seed companies.

The consequences of low temperature in wheat are reported to be increased ROS concentrations in the seeds, which disturb several biological mechanisms and cause an imbalance between the ability of leaves to absorb light and release energy to the cells to perform essential metabolic activities ${ }^{51,52}$. Considering that there is an estimated high demand for wheat in the future due to the rising population ${ }^{53}$ and climate change, Li et al. ${ }^{40}$ improved the cold tolerance of wheat plants with osmopriming treatment in seeds $(30 \mathrm{mM} \mathrm{NaCl})$. The priming procedure successfully enhanced the photochemical efficiency in seedlings by decreasing MDA accumulation and alleviating cell death. Lower MDA activity indicates a decrease in lipid peroxidation, which maintains the integrity of the membrane and leads primed seeds to a better germination performance ${ }^{54}$. In another study, Zhang et al. ${ }^{55}$ investigated the physiological and biochemical effects of osmopriming (PEG 8000 solution) on the germination performance and seedling establishment of sorghum [Sorghum bicolor (L.) Moench] under various soil moisture 
conditions. The experiment provided promising results concerning uniform emergence and decreased drought stress for suitable seedling establishment. The priming procedure strengthened the antioxidant activities of $P O D, C A T, S O D$, and $A P X$, which led to the enhancement of drought tolerance in sorghum plants.

\subsection{Chemopriming}

Chemopriming involves inorganic substances, such as hydrochloric acid ( $\mathrm{HCl})$, selenium (Se), fungicides and pesticides, or organic substances, such as essential oils, dairy products and crude plant extracts. Biochemical changes, such as antioxidant activity, are one of the most common improvements in seeds treated with chemopriming, leading to a reduction in heavy metal uptake ${ }^{56}$, tolerance to chilling ${ }^{57}$, salinity ${ }^{58}$, and drought stress ${ }^{59}$ in several crop plants ${ }^{60}$.

Considered one of the most aggressive abiotic stresses, chilling conditions significantly decrease the germination index, leading to poor seedling growth of crop plants by reducing starch metabolism and lowering the respiration rate. Many crop plants are very sensitive to chilling stress during germination ${ }^{61}$. Hussain et al. ${ }^{57}$ studied the physiological and biochemical mechanisms of rice cultivars primed with several methods and then subjected to chilling stress $\left(18{ }^{\circ} \mathrm{C}\right)$. The application of selenium $(50 \mu \mathrm{M})$ was shown to be one of the most effective treatments compared to osmopriming (calcium chloride: $100 \mathrm{mg} \mathrm{L}^{-1}$ ), redox priming (hydrogen peroxide: $50 \mu \mathrm{M}$ ), and hormopriming (salicylic acid: $100 \mathrm{mg} \mathrm{L}^{-1}$ ), allowing rice to thrive under chilling stress. The investigation also found that chemopriming treatment induced several physiological activities, such as peroxidase, catalase, and superoxide dismutase, and enhanced the accumulation of glutathione and free proline at the seedling stage, which provided a strong antioxidative defense system under chilling stress.

Another constraint experienced by farmers around the world, especially in Asian countries, is the high levels of arsenic-contaminated groundwater in rice cultivation, which is considered a limitation for normal rice growth, reducing germination by $70 \%$ in some cases. A study with chemopriming (selenium: $0.8 \mathrm{mg} \mathrm{L}^{-1}$ ) treatment in rice under arsenic stress conditions demonstrated an enhancement of germination, shoot length, and seedling biomass ${ }^{56}$. In this case, the plant responses to chemopriming were reflected in the enhancement of biological mechanisms due to the reduction in arsenic uptake, hence suppressing oxidative damage by increasing antioxidant accumulation in rice seedlings. In another case with heavy metals in the soil, nickel stress resistance [at $50 \mathrm{ppm} \mathrm{Ni}\left(\mathrm{NO}_{3}\right)_{2}$ ] was detected in zucchini seedlings (Cucurbita pepo L. cv. Courgette d'Italie) by chemopriming with $\mathrm{H}_{2} \mathrm{~S}$ and $\mathrm{CaCl}_{2}{ }^{62}$. In this study, chemopriming induced postgerminative crossadaptation by improving photosynthetic pigments and seedling biomass, as well as increasing the content of ascorbate, total thiols, and glutathione reductase activity in leaves, while ascorbate peroxidase activity decreased significantly.

\subsection{Hormopriming}

Phytohormones naturally mediate the regulation of biological mechanisms in plant species ${ }^{4,63}$. Abscisic acid, auxin, brassinosteroids, cytokinins, ethylene, gibberellins, jasmonates, salicylic acid, and strigolactones are phytohormones involved in regulating seed dormancy, 
germination and plant development, as well as defense responses to environmental stressors $4,64,65$. These substances have been evaluated in experimental studies to detect plant responses to unsuitable environmental conditions ${ }^{66,67}$, which may help the development of tools and specific protocols for enhancing crop plant production.

Hormopriming is considered one of the most effective methods and is widely applied by seed companies to improve stress tolerance in crop plants, such as drought in maize ${ }^{68}$, salinity in wheat ${ }^{69}$ and chilling in rice ${ }^{70}$. $\mathrm{ABA}$ and GAs are recognized to control physiological, biochemical, and molecular mechanisms in tomato, such as germination, seedling growth, transportation and partitioning of specific nutrients, and reprogramming of gene expression, as reported by Nakaune et al. ${ }^{6}$. Knowledge about the dynamic changes in phytohormone and gene expression during seed priming and during germination may facilitate understanding of the biological mechanism to develop new concepts and specific technologies to improve agronomic traits. For instance, Yang et al.22 shed light on the biological mechanism underlying rapid germination in tomato seeds treated with hormopriming, discussing the dynamic changes in the transcript levels involved in the ABA and GA pathways. The study detected higher expression levels of SICYP707A2, which is considered an important catabolic enzyme in the ABA pathway and maintains the low concentration of $\mathrm{ABA}$, in seeds with rapid germination rates.

The deleterious effect of chilling and drought conditions on the germination and development of plants is, in part, because it induces the accumulation of a large amount of ROS ${ }^{71-73}$. Moreover, chilling and drought conditions cause reductions in carbohydrates, lipids, and proteins, resulting in cell damage. Most rice varieties are sensitive to lowtemperature conditions during germination and seedling development, leading to severe economic losses ${ }^{74,75}$. Wang et al. ${ }^{70}$ investigated the effects of seed hormopriming (salicylic acid) against chilling stress on rice germination and seedling growth. The results showed increasing germination performance and enhanced morphological attributes, such as length of shoots and weight of shoots, and weight of roots. In this case, the agronomic improvements were correlated with higher $\alpha$-amylase activity and total soluble sugar content. In accordance with these results, Pál et al. ${ }^{76}$ suggested a similar response to hormopriming in the enhancement of plant tolerance to chilling stress by modifying the antioxidant activity system. As a natural response to stress, priming seed methods induce higher $\alpha$-amylase and/or $\beta$-amylase activity, which results in an increased breakdown of starch and subsequent buildup of sugar levels. These enzymes play pivotal roles in mitigating environmental stress by increasing the rate of respiration, improving germination speed, and promoting suitable seedling emergence and establishment in plants ${ }^{77}$.

Exogenous application of methyl jasmonate $(20 \mu \mathrm{M})$ and/or salicylic acid ( $2 \mathrm{mM}$ ) in maize (Zea mays L.) seeds showed the ability to improve physiological and biochemical attributes under drought stress in comparison to hydropriming 68 . Likewise, Samota et al. ${ }^{78}$ primed droughttolerant and drought-sensitive rice seeds with methyl jasmonate or salicylic acid under drought conditions. The experiment detected effective growth and development of plants because of the mitigating of damaging effects of drought stress on the plant by increasing antioxidant activities in the shoot, lowered lipid peroxidation, reduced protein oxidation, and upregulated expression of drought-responsive genes. In 
another study, exogenous hormone application (5 mM GA3) improved the germination and establishment of alfalfa (Medicago sativa) seedlings under saline conditions $(200 \mathrm{mM} \mathrm{NaCl})$ by enhancing the activities of antioxidant enzymes (CAT, SOD, and APX) and reducing membrane damage ${ }^{79,80}$.

\subsection{Nanopriming}

Nanotechnology is an advanced method for agriculture because it has shown promising agronomic responses for a wide range of crop plants ${ }^{81,82}$. Nanoparticles have demonstrated enhanced biological activity in plants via nanofertilizers ${ }^{83}$ and reduced toxicity of nanoherbicides ${ }^{84}$ and nanopesticides ${ }^{85}$ in recent decades ${ }^{86}$.

Nanopriming agents, such as silver and zinc oxide nanoparticles ${ }^{87-}$ 90, have been used to enhance germination indexes and seedling establishment in several plant species: O. sativa ${ }^{91}$, Carthamus tinctorius ${ }^{92}$, Citrullus lanatus ${ }^{93}$, and Thymus kotschyanus ${ }^{94}$. Moreover, nanopriming is one of the most efficient methods to induce salt tolerance capacity in plants by enhancing physiological and biochemical responses ${ }^{95}$. In this context, Shafiq et al. ${ }^{96}$ detected improvements in agronomic traits of wheat plants treated with fullerenol nanopriming $(0,10,40,80$ and 120 $\mathrm{nM}$ concentration) under salt stress $(150 \mathrm{mM} \mathrm{NaCl})$. The study showed that fullerenol induced better $\mathrm{K}^{+}, \mathrm{Ca}^{2+}$ and $\mathrm{P}$ uptake, which was reflected in better ionic and ROS homeostasis and conferred grain yield recovery by plant stress resilience. Another study evaluated the germination indexes and seedling enhancement of sorghum [S. bicolor (L.) Moench] treated with nanoiron oxide $\left(\mathrm{n}-\mathrm{Fe}_{2} \mathrm{O}_{3}\right)$ under salt stress $(150 \mathrm{mmol} \mathrm{NaCl}$ solution $)^{97}$. The results demonstrated significant salt tolerance in plants treated with nanopriming through physiological improvements, such as photosynthetic rate, chlorophyll index, photosystem II efficiency, and relative water content, with the aim of decreasing membrane damage.

Further investigations at the molecular point of view, although scarce in nanopriming studies, would allow researchers to develop agronomic strategies to enhance crop production under stress conditions and to utilize natural resources more efficiently.

\subsection{Matrix priming $(M P)$}

In MP, seeds are mixed with organic/inorganic solid or semisolid water carriers (charcoal, clay, peat moss, sand, sawdust, vermiculite) during imbibition and incubated for a predetermined photoperiod with controlled temperature and oxygen availability ${ }^{23,98,99}$. In this procedure, the matrix potential of the priming solution with high water-holding capacity induces a slowdown of solute uptake by seeds, similar to the water soaking phenomenon experienced by seeds in a natural environment. Then, seeds are separated from the matrix and dried to near the initial moisture level. The procedure is flexible (by mixing with other materials), cost-effective, and able to treat a large number of seeds ${ }^{100}$. Important enhancement in crop production has been noted in many reports for the use of MP under environmental stress, such as drought ${ }^{23}$, salinity ${ }^{101}$, and low temperature ${ }^{102}$.

In an attempt to establish a protocol for MP, a classic investigation used artificial soil media in flats under supra-optimal temperature in comparison to polyethylene glycol (8000), inorganic salts, and nontreated seeds ${ }^{98}$. The study detected that tomato (L. esculentum), carrot (Daucus carota) and onion (Allium cepa) treated with MP improved seedling 
emergence by $50 \%$ and increased the dry weight by acquiring thermotolerance compared to nontreated seeds. In another study, broccoli and cauliflower seeds were subjected to MP (vermiculite and water) for two days of incubation ${ }^{101}$. Salt stress $(50,100,150$ or $200 \mathrm{mM}$ $\mathrm{NaCl}$ ) was mitigated with MP treatment by increasing the physiological attributes and biochemical activity, such as peroxidase and catalase, and the contents of proline, soluble sugar, and protein in both plant species. In this case, the accumulation of proline and soluble sugar in cells, as well as the high activities of protective enzymes, aided in enhancing salinity tolerance in broccoli and cauliflower. Moreover, the great availability of $\mathrm{O}_{2}$ to the seeds during the MP procedure may help the respiratory system, since it directly affects seed vigor ${ }^{103}$. In another study, Sen et al. ${ }^{104}$ investigated the physiological and biochemical responses in mung beans (Vigna radiata) through MP with chitosan to overcome the adverse effects of salinity stress. Chitosan is recognized due to its biodegradability, bioactivity, biocompatibility, and nontoxicity to crop plant production. MP treatment significantly reduced the $\mathrm{H}_{2} \mathrm{O}_{2}$ and MDA content and increased the accumulation of protein, antioxidant activity, and phenolic compounds, leading to better plant growth-promoting traits.

\subsection{Biopriming}

Although it is not widely used in crop plant production, biopriming is an emerging, ecofriendly and promising method in which strains of Bacillus spp., Enterobacter spp., Pseudomonas spp., and Trichoderma spp., among others, are applied to seeds to improve germination indexes and uniformity, as well as seedling vigor and growth parameters ${ }^{24,105}$. In this method, the inoculation of beneficial microorganisms in seeds is able to colonize the rhizosphere, reducing seed and soilborne pathogens and hence improving the endophytic relationships with the plant ${ }^{34,105-108}$. Despite few investigations of agronomic performance ${ }^{109}$, biopriming has shown great synergistic potential between microorganisms and plants in inducing biotic and abiotic resistance ${ }^{12,110-113}$.

Mycorrhizal fungi have the natural potential to activate the aggregation of several important proteins and transcripts on the roots, which improves the plant defense mechanism system ${ }^{114}$. Rozier et al. ${ }^{108}$ used plant growth-promoting rhizobacteria (Azospirillum lipoferum) in maize cultivars, which improved the germination rate and seedling defense system by stimulating biochemical and physiological activity. In another experiment with biopriming, Trichoderma harzianum promoted drought tolerance in wheat through physiological protective mechanisms and increased phytopathogen resistance ${ }^{115}$. Additionally, working with Trichoderma as a biopriming agent in wheat, Meena et al. ${ }^{116}$ reported enhancements in height, root length, yield, and chlorophyll content in different soil conditions. The study detected the improvement of nitrogen use efficiency, which is considered a relevant agronomical trait, since approximately $50 \%$ of the $\mathrm{N}$ applied to the field in intensive agricultural production systems is lost through leaching, surface runoff, volatilization, denitrification, and microbial consumption ${ }^{117,118}$.

Biopriming has been investigated as a disease management method because endophytic microorganisms can reduce biotic stress, which helps the biological system defend against phytopathogens ${ }^{119}$. In this way, Singh et al. ${ }^{120}$ reported phytopathology control (Rhizoctonia solani) in maize treated with biopriming (Pseudomonas aeruginosa) via enhancement of antioxidative defense enzymes. A significant enhancement in 
physiological and biochemical responses was detected in maize plants treated with biopriming, such as activation of the phenylpropanoid pathway and enhanced accumulation of proline. The study also detected a significant regulation of stress-responsive genes (PR-1 and $P R-10)$. In pearl millet [Pennisetum glaucum (L.) R. Br], biopriming with Pseudomonas fluorescens improved the germination and growth indexes and promoted resistance against downy mildew disease (Sclerospora graminicola) by physiological changes ${ }^{121}$.

\subsection{Physical priming}

\subsubsection{Heat/Cold priming}

Temperature stress limits crop production and threatens global food security ${ }^{122,123}$. Crop plants that experience unsuitable environmental temperatures at the seed germination, seedling growth, and/or vegetative stage may impact negative effects on yield productivity through a cascade of physiological, biochemical, and molecular changes ${ }^{124-126}$. Efficient photosynthesis and photosynthetic partitioning are required for normal plant development. Considering that photosynthesis is highly sensitive to temperature, heat stress may disrupt chloroplast structures and their specific functions, decreasing the chlorophyll amount and stimulating the loss of crop production ${ }^{127}$.

In heat/cold priming, seeds are subjected to different temperatures for a predetermined period with minimal physiological impact. The seeds treated with heat/cold priming techniques allow activating biological mechanisms such as osmolytes and antioxidative defense, which are responsible for improving germination and plant development by reducing thermoinhibition. Heat priming is able to induce stressresponsive proteins (heat-shock proteins and late embryogenesis abundant proteins) and reprogram metabolic homeostasis and, which confers significant thermotolerance, allowing plants to withstand subsequent thermal stresses ${ }^{13,128,129}$. In this context, heat stress was conducive to a significant grain yield reduction in winter wheat, while heat primed seeds ( $40{ }^{\circ} \mathrm{C}$ for four hours) did not show such a loss of yield $^{130}$. The study detected improvements in photosynthesis and antioxidant activity by gene expression modifications that lead to the thermotolerance of winter wheat plants. Although heat/cold priming in seeds has shown satisfactory results in crop production, most heat/cold priming investigations are made in vegetative tissues and rarely in seeds ${ }^{131}$.

Previous reports have studied the biological mechanisms of heat/cold priming to overcome the stress induced by temperature changes ${ }^{125,132,133}$. Moderate temperature as a priming treatment has shown physiological improvement in relation to stress tolerance under high temperatures in Agrostis stolonifera L. ${ }^{134}$. The study suggested that heat tolerance is a natural response to the higher concentration of saturated fatty acids in the leaf membranes. In another investigation, cold priming ameliorated cold stress in chickpeas ${ }^{135}$. Seeds were primed at $5{ }^{\circ} \mathrm{C}$ for 30 days, and plants were raised in a controlled environment. Cold stress negatively affected the biological mechanisms of chickpea plants, such as photosynthetic ability and photoassimilation capacity, and decreased the redox status of the cells and the production of osmolytes. Cold tolerance ability was detected in primed plants at the reproductive stage, according to the authors because of the improved leaf function, such as hydration status and photosynthetic and carbon fixation ability, in comparison to 
plants without priming treatment. Thus, although less information is available on the biological mechanism and molecular changes in seeds subjected to heat/cold priming, this method may contribute to inducing thermotolerance in crop plants for hotspot regions of warming levels of temperature changes ${ }^{136}$.

\subsubsection{Cold plasma priming}

Cold plasma is an ecofriendly and cost-effective priming method to efficiently improve crop plant production ${ }^{133,137-139}$. Cold plasma priming involves the application of a mixture with ionized gas, positively charged particles, electrons, and neutral gas to seeds, which stimulates biological mechanism changes, such as the density of reactive oxygen species, phytohormone catabolism, reactive nitrogen species, and electrical conductivity ${ }^{139,140}$. According to several authors, in addition to eliminating phytopathogen contamination, this priming process also modifies the seed surface and facilitates the seed water uptake capacity, breaking dormancy and thus triggering modifications in hormones ${ }^{133}$, the proteome $^{141}$, secondary metabolites ${ }^{142}$, and tissue differentiation ${ }^{143}$, leading to fast germination and better seedling growth and improving tolerance to environmental stress ${ }^{133,137,139,140,144}$.

In previous studies, physiological and biochemical responses were enhanced by cold plasma exposure in many crop plants: T. aestivum and A. sativa ${ }^{145}$, O. sativa L. ${ }^{18}$, Gossypium hirsutum L. ${ }^{146}$, Pisum sativum L. and Cucurbita pepo L. ${ }^{147}$. Seed treated with cold plasma has shown long-term effects at a later stage, such as the seedling stage ${ }^{133,139}$, to cope with biotic and abiotic stressors, such as drought stress and disease stress. For instance, Jiang et al. ${ }^{137}$ reported that the exposure of tomato seeds to cold plasma $(80 \mathrm{~W})$ efficiently increased germination and growth response and regulated the defense mechanism system in the resistance to bacterial wilt (Ralstonia solanacearum). Similarly, Li et al. ${ }^{144}$ reported that cold plasma treatment $(120 \mathrm{~W})$ in peanuts improved the germination rate, increased the shoot and root dry weights, and improved yield in comparison to the nonprimed treatment. Such improvements are related to the leaf area, nitrogen concentrations, and chlorophyll content increasing in response to cold plasma treatment. In another study, tomato seeds primed with cold plasma improved the germination potential and seedling growth rate under drought stress ${ }^{133}$. Moreover, the study detected improvements in antioxidant activity, phytohormone synthesis, and defense gene expression ( $\beta$-1,3-glucanase) of tomato seedlings. Although cold plasma seed priming has shown promising results in crop plant production, the biological changes and their regulation in several crop plants to mitigate biotic/abiotic stress remain unclear. With the current advances in plasma technologies, future studies could focus on plasma-triggered modifications in the cellular transcription program of genes, concentrations of hormones, and proteome issues to improve the knowledge about the complex biological mechanism changes in crop plants under stress conditions.

\subsection{Hybrid priming}

The physiological, biochemical, and molecular responses in seeds subjected to a single priming method are considered difficult to understand in the biological system that controls biotic/abiotic stress resistance. However, understanding the plant response becomes more complex when hybrid priming (combined priming procedures) is applied 
to seeds ${ }^{14}$, plants ${ }^{148}$, or both ${ }^{149}$ because different priming methods promote different effectiveness in plants. In this way, considering that crop plants during their lifespan are commonly exposed to several environmental conditions, such as drought, salinity, heat/cold/freezing, and/or phytopathogens, hybrid priming treatments of seeds may be effective and a desirable method to increase multiple stress tolerances in crop plants.

Hybrid priming, a method of multiple priming combined in a specific procedure, commonly acts synergistically with priming agents, promoting agronomical attribute improvements 14 through phytohormone regulation ${ }^{141,150}$, reprogramming of gene expression ${ }^{21}$, and changes in biological mechanisms ${ }^{151}$. For instance, single electrostatic field is a priming method ${ }^{152}$ used to recover seed vigor ${ }^{14}$ and to induce fast germination and plant growth in crop plants ${ }^{16,153,154}$. In this procedure, seeds are exposed to electrical current (kilovolts/centimeters) for a predetermined time, which promotes some biological changes, such as superoxide dismutase activities in onion seeds ${ }^{14}$ and antioxidant metabolism in wheatgrass ${ }^{152}$. In the same way, single hydropriming is considered a relevant technique to overcome environmental stressors 33,155 , as mentioned in section 2.1 (Hydropriming). Thus, while single electrostatic field and single hydropriming improve limited biological changes, hybrid priming technology allows more biological changes to crop plants. Zhao et al. ${ }^{14}$ developed a novel hydro-electro hybrid priming (HEHP) method to recover the potential vigor of onion seeds. They subjected the seeds to hydropriming $(5 \mathrm{~h})$ followed by electrostatic field irradiation (10 kv/cm for $40 \mathrm{~s}$ ), incubation and desiccation (Fig. 4).

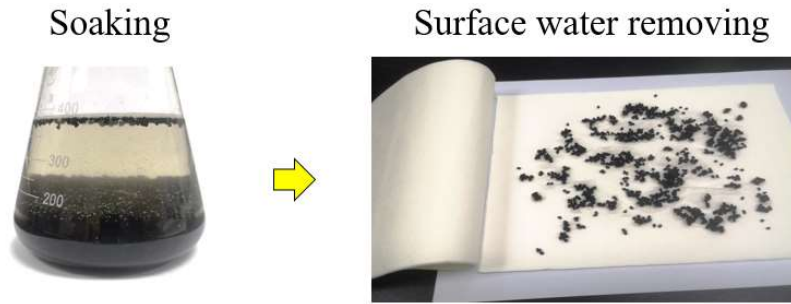

Desiccation by air-drying

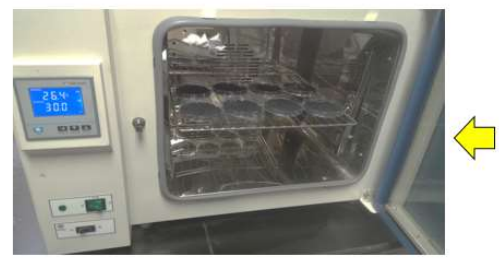

Incubation

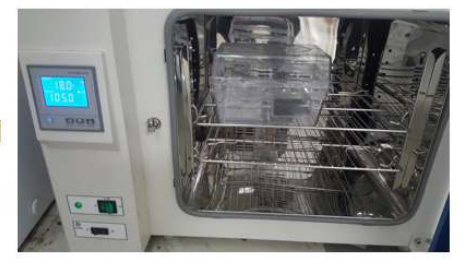

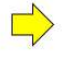

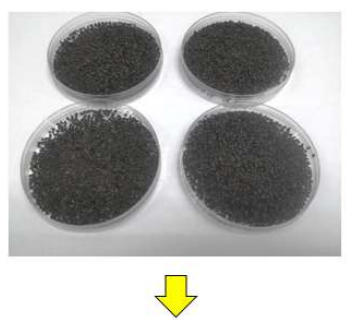

Electrostatic field irradiation

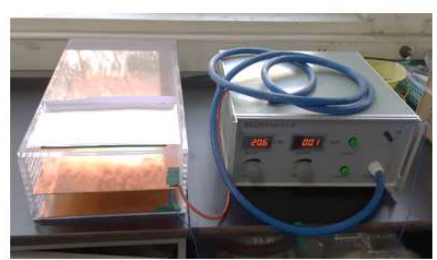

Figure 4. Hybrid priming procedure (hydro-electro hybrid priming ${ }^{14}$ ).

The combined priming method successfully recovered the potential vigor index of onion seeds (612.38) via biological mechanism changes in comparison to single hydropriming (490.26), single electrostatic field irradiation (454.85), and no priming (212.87). In the same way, our previous investigation adopted a similar HEHP method to achieve the rapid germination of tomato ( $S$. lycopersicum var. HaoMei) with low vigor $^{156}$. Potential synergism was detected between the priming 
procedures (hybrid priming) in phytohormone regulation (ABA/GA) and reprogramming of gene expression (SINCED2 and SIDELLA), which reflected the enhancement of germination indexes and vigor responses (5.09; 127) in comparison to single hydropriming (3.19; 57.42), single electrostatic field irradiation $(2.47 ; 14,82)$ and no priming $(2.78 ; 13.85)$. Moreover, the study detected vigor improvement of tomato seeds stored for 60 days (446.59) with HEHP samples in comparison to primed seeds without storage (127). Thus, HEHP was demonstrated to be a promising and flexible method for adaptation in other crop plants.

Compared with the efforts made to study the single priming effect to increase stress tolerance in crop plants, the biological response of plants subjected to multiple priming procedures has drawn less attention until recently, as observed by previous reports ${ }^{14,157}$. Hassini et al. ${ }^{158}$ improved broccoli (B. oleracea L. var. Italica) sprout growth and quality under salinity stress $(150 \mathrm{mM} \mathrm{NaCl})$ by combined priming with $\mathrm{KCl}(50$ $\mathrm{mM}$ ) and methyl jasmonate. Górnik and Lahuta ${ }^{151}$ combined 24epibrassinolide $\left(10^{-6}, 10^{-8}\right.$ and $\left.10^{-10} \mathrm{M}\right)$, salicylic acid or jasmonic acid $\left(10^{-2}\right.$, $10^{-3}$ and $10^{-4} \mathrm{M}$ ) with hydropriming ( $15 \%$ moisture content) followed by heat shock treatment $\left(2 \mathrm{~h}\right.$ at $\left.45^{\circ} \mathrm{C}\right)$ on sunflower seeds and then subjected them to chilling conditions $\left(21\right.$ days at $\left.0{ }^{\circ} \mathrm{C}\right)$ and a recovery period $(72 \mathrm{~h}$ at $25{ }^{\circ} \mathrm{C}$ ). The combined priming method increased the resistance of seedlings to chilling stress conditions mainly by promoting the activity of catalase and sugar metabolism, which alleviated the decrease in Fv/Fm. In another experiment, $\mathrm{Li}$ et al. ${ }^{21}$ reported the ability of hybrid priming with exogenous salicylic acid and $\mathrm{H}_{2} \mathrm{O}_{2}$ to enhance the chilling tolerance $\left(13^{\circ} \mathrm{C}\right)$ of maize. Seed vigor and seedling establishment under chilling stress were improved in hybrid priming seed treatment. The synergistic effects of combined priming induced positive changes in the antioxidant system and hormone activity and increased the metabolites and energy supply, thereby providing biological conditions to enhance chilling tolerance in maize. In this case, the hybrid priming method induced the upregulation of gene expression related to GA biosynthesis, ZmGA20ox1 and $Z m G A 30 o x 2$, and induced the downregulation of gene expression related to GA catabolism, ZmGA2ox1, while ABA catabolism gene

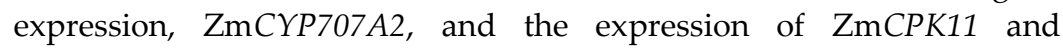

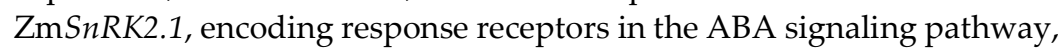
were all upregulated. The gene $Z \mathrm{~m} R G L 2$, responsible for germination inhibition ${ }^{159}$, was decreased in the hybrid priming treatment.

Thus, optimization and standardization of priming agents, as well as specific procedures, are required for each crop plants in the hybrid priming method according to local environmental adversity conditions to improve crop plant productivity.

\section{Research Gaps and Future Perspectives}

Faced with climate change, limited natural resources and the everincreasing population around the globe, improved crop plant production with the development of new technologies that are agronomically efficient, feasible, cost-effective and, if possible, ecofriendly is urgent. Accumulated evidence has shown promising crop productivity when seeds are exposed to single or multiple priming procedures to enhance stress tolerance. Future studies with seed priming procedures may focus on the molecular level, in accordance with a proteomic and/or metabolomics approach, to identify and track the stress-responsive genes during and after priming procedures, as well as during plant 
development. Such studies may generate valuable results to determine the priming procedure for each plant species to enhance crop production under local adverse environmental conditions. Moreover, this work strongly encourages researchers to combine two or more priming procedures, and the use of this priming method may be valuable to synergistically activate biological mechanisms and enhance tolerance towards multiple biotic/abiotic stresses. Finally, seed companies may widely adopt priming technology as a key strategy to increase crop plant production under adverse environmental conditions. 
Table 1. Synopsis of studies on seed priming procedures in the improvement of crop species productivity under stress conditions.

\begin{tabular}{llllll}
\hline Crop species & Priming procedure & Stress condition & Germination and seeding & Crop performance and Reference \\
(scientific & (rate of application) & growth response & biological & mechanisms \\
name/common & & & & \\
name) & & & & \\
\hline
\end{tabular}

\section{Hydropriming}

\begin{tabular}{|c|c|c|c|c|c|}
\hline $\begin{array}{l}\text { Helianthus annuus L. } \\
\text { cv. Sanbro/Sunflower }\end{array}$ & Soaked $\left(18 \mathrm{~h}\right.$ at $\left.25^{\circ} \mathrm{C}\right)$ & $\begin{array}{l}\text { Drought stress }(0,-0.3,-0.6 \text {, } \\
-0.9,-1.2 \mathrm{MPa} \text { of osmotic } \\
\text { potential }), \text { and salinity } \\
\text { stress }(\mathrm{NaCl}: 0.0,6.5,12.7 \text {, } \\
18.4 \text { and } 23.5 \mathrm{dS} \mathrm{m}^{-1} \\
\text { electrical conductivity) }\end{array}$ & $\begin{array}{l}\text { Fast and uniform germination, } \\
\text { low abnormal seedling } \\
\text { percentage }\end{array}$ & $\begin{array}{l}\text { Increased salt and drought } \\
\text { tolerance, enhancement of fresh } \\
\text { weight }\end{array}$ & Kaya et al. ${ }^{33}$ \\
\hline $\begin{array}{l}\text { Lupinus angustifolius } \\
\text { L./Lupine bean }\end{array}$ & Soaked $\left(3 \mathrm{~h}\right.$ at $\left.20^{\circ} \mathrm{C}\right)$ & $\begin{array}{l}\text { Low temperature }\left(7^{\circ} \mathrm{C}\right) \text { and } \\
\text { control }\left(13^{\circ} \mathrm{C}\right)\end{array}$ & $\begin{array}{l}\text { Improved germination } \\
\text { performance }\end{array}$ & $\begin{array}{l}\text { Enhanced crop productivity via } \\
\text { protection against low temperature } \\
\text { damage; decreased the cell } \\
\text { membrane permeability and ABA } \\
\text { level }\end{array}$ & Płażek et al. ${ }^{31}$ \\
\hline $\begin{array}{l}\text { Medicago truncatula } \\
\text { var. Jemalong/Barrel } \\
\text { medic }\end{array}$ & Soaked ( $2 \mathrm{~h}$ and $4 \mathrm{~h})$ & $\begin{array}{l}\text { Contaminated soil with } \\
\text { solid waste from abandoned } \\
\text { agricultural areas }\end{array}$ & $\begin{array}{l}\text { Enhanced seed germination } \\
\text { percentage and seedling } \\
\text { establishment by ameliorating } \\
\text { water uptake }\end{array}$ & $\begin{array}{l}\text { Upregulation of gene expression in } \\
\text { DNA damage repair and } \\
\text { antioxidant defense; improved } \\
\text { biomass }\end{array}$ & Forti et al. ${ }^{34}$ \\
\hline
\end{tabular}




\begin{tabular}{|c|c|c|c|c|c|}
\hline $\begin{array}{l}\text { Moringa oleifera } \\
\text { Lam./Moringa }\end{array}$ & $\begin{array}{l}\text { Aerated water }(12 \mathrm{~h} \text { and } \\
24 \mathrm{~h})\end{array}$ & $\begin{array}{l}\text { Salinity levels }(3,6,10,14 \\
\left.\mathrm{dS} \mathrm{m}^{-1}\right)\end{array}$ & $\begin{array}{l}\text { Enhanced moringa } \\
\text { germination at } 10 \mathrm{dS} \mathrm{m}^{-1}(12 \mathrm{~h})\end{array}$ & $\begin{array}{l}\text { Improved the biomass yield, } \\
\text { increased the chlorophyll a and } b \text {, } \\
\text { and total phenolic content }\end{array}$ & Nouman et al. ${ }^{160}$ \\
\hline Oryza sativa/Rice & Soaked (24 h) & Flooded soil condition & $\begin{array}{l}\text { Enhanced the emergence and } \\
\text { seedling growth }\end{array}$ & $\begin{array}{l}\text { Improved crop establishment, } \\
\text { increased the rice tolerance to } \\
\text { anaerobic conditions via } \\
\text { maintenance of high } \alpha \text {-amylase } \\
\text { activity and subsequent increase in } \\
\text { soluble sugars, and maintain lower } \\
\text { MDA concentrations }\end{array}$ & Mondal et al. ${ }^{32}$ \\
\hline
\end{tabular}

\section{Osmopriming}

Brassica napus L. cv. Polyethylene glycol (- Salinity stress (NaCl:100 Improved germination and Enhanced salinity tolerance by upregulation of the P5CSA gene, downregulation of the $P D H$ gene and accumulated hydrogen peroxide contents

Brassica rapa subsp. Urea $(200 \mathrm{mmol} / \mathrm{L})$ or Drought stress $(0,-1.0,-2.0$, Increased germination traits at Priming seeds increased CAT, SOD Yan ${ }^{161}$ pekinensis $\quad \mathrm{cv} . \mathrm{KNO}_{3}(200 \mathrm{mmol} / \mathrm{L})-3.0,-4.0,-5.0 \mathrm{MPa}$ of all levels of drought stress as and $P O D$ activity and the Lainong $50 /$ Chinese solution at $20^{\circ} \mathrm{C}$ for $8 \mathrm{~h} \quad$ osmotic potential) compared to the unprimed accumulation of proline, and cabbage treatments soluble sugar content leading to drought tolerance enhancement 
Oryza sativa L. (var. $\mathrm{NaCl}$ solution (50 or 75 Salinity stress with $\mathrm{NaCl}$ Osmopriming showed high Enhanced the stress-tolerance Sen and Puthur ${ }^{162}$ Neeraja, Vaisakh and $\mathrm{mM}$ for $12 \mathrm{~h}$ ) Vyttila 6)/Rice

(75 $\mathrm{mM}$ - Neeraja and positive impacts Vaisakh, $100 \mathrm{mM}$ - Vyttila germination indexes 6) and PEG (15\% - Neeraja, seedling establishment $20 \%$ - Vaisakh and Vyttila

6)

Sorghum bicolor (L.) PEG 8000 solution (48 h Moench cv. Liao at $18^{\circ} \mathrm{C}$ ) waxy No. 3/Sorghum )$$
\text { field }
$$
field capacity $(25 \%$ of moisture content), drought stress $(15 \%$ soil moisture content), excessive soil moisture $\quad(35 \% \quad$ soil moisture content)

Triticum aestivum L. Potassium silicate $(0,1$, Saline water from Lake var. Chamran/Wheat 1.5 and $2 \mathrm{mM}$ for $6 \mathrm{~h}$ ); Urmia (Iran) was diluted to Lake Urmia saline water produce salinities with $(0,100,150$ and $200 \mathrm{mg}$ electrical conductivities $\mathrm{L}^{-1}$ of salt concentration $\quad(\mathrm{EC})$ of $2,4,6,8,10,12,14$, for $10 \mathrm{~h}) \quad 20 \mathrm{dS} \mathrm{m}^{-1}$, while distilled water $\left(\mathrm{EC} \approx 0 \mathrm{dS} \mathrm{m}^{-1}\right)$ was used for the control

Triticum aestivum $\quad \mathrm{CaCl}_{2}$ solution (1.5\% for

\section{L./Wheat} $12 \mathrm{~h}$ )

$$
\text { capacity) }
$$

Uniform and synchronous emergence, and decreased stress for suitable germination

ton

Enhanced the vitality of seeds, and improved the development of seedlings

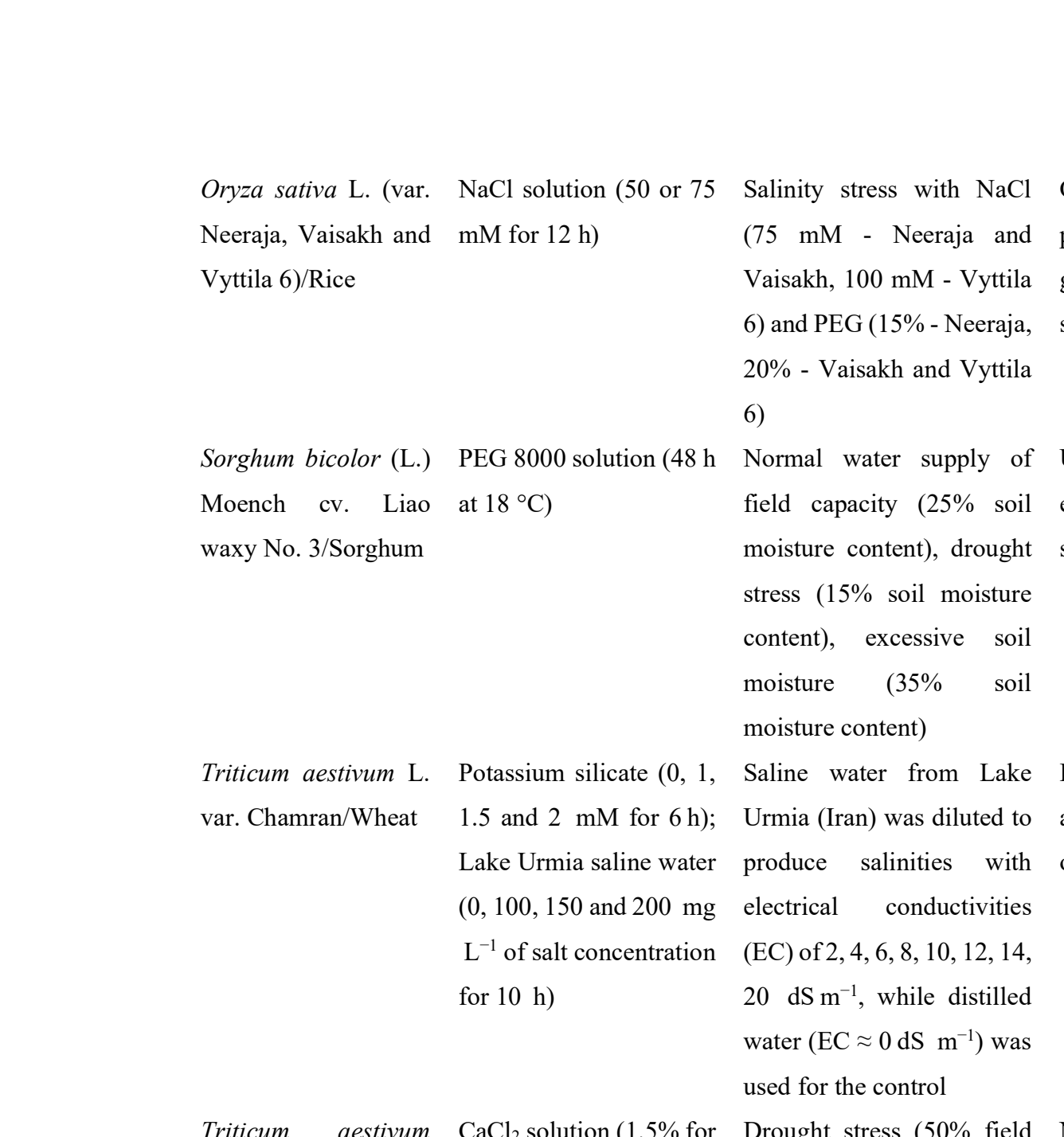

were recorded

on potential of sensitive and tolerant

and varieties; improved the enzymatic antioxidant contents and antioxidant enzymes activity

Enhancement of antioxidant Zhang et al. ${ }^{55}$ activities of $A P X, C A T, P O D$, and $S O D$; increased stress tolerance of plants under drought conditions; improved chlorophyll content and better root viability

Improved salt tolerance; increased Feghhenabi al. ${ }^{50}$ vitality index of plant development
as well as length and dry weight area, tissue water status, osmolytes accumulation and grain yield; and improved drought tolerance 
Triticum aestivum $\mathrm{L} . \quad \mathrm{NaCl}$ solutions $(10,30, \quad$ Low-temperature cv. Jimai44/Wheat and $50 \mathrm{mM}$ )

$\left(2{ }^{\circ} \mathrm{C}\right.$ for $\left.24 \mathrm{~h}\right)$

stress No germination were recorded
Cold tolerance improvement by $\mathrm{Li}$ et al. ${ }^{40}$ enhancement of photochemical efficiency; priming decreased MDA accumulation and induced cell death alleviation

\section{Chemopriming}

\begin{tabular}{|c|c|c|c|c|c|}
\hline $\begin{array}{l}\text { Beta vulgaris } \\
\text { L./Sugar beet }\end{array}$ & $\begin{array}{l}\text { Tryptophan }(0.0,2.5, \\
\text { and } 5.0 \mathrm{mM})\end{array}$ & $\begin{array}{l}\text { Salinity stress }(320,2000 \text {, } \\
4000,6000 \text {, and } 8000 \mathrm{ppm})\end{array}$ & $\begin{array}{l}\text { No germination responses } \\
\text { were recorded }\end{array}$ & $\begin{array}{l}\text { Increased growth, yield and root } \\
\text { quality; reduced the negative effect } \\
\text { of salinity stress by the highest } \\
\text { content of chlorophyll-a and } \\
\text { chlorophyll-a/b ratio, as well as } \\
\text { carotenoids content }\end{array}$ & Hozayn et al. ${ }^{163}$ \\
\hline $\begin{array}{ll}\text { Oryza sativa L. } & \text { L. } \\
\text { Huanghuazhan } & \\
\text { (inbred) } & \text { and } \\
\text { Yangliangyou6 } & \\
\text { (hybrid)/Rice } & \end{array}$ & Selenium $(50 \mu \mathrm{M})$ & Chilling stress $\left(18^{\circ} \mathrm{C}\right)$ & $\begin{array}{l}\text { Improved the germination } \\
\text { percentage }\end{array}$ & $\begin{array}{l}\text { Mitigates chilling stress; triggered } \\
\text { physiological activities, such as } \\
S O D, P O D \text {, and } C A T \text {, and } \\
\text { enhanced the accumulations of } \\
\text { glutathione and free proline; } \\
\text { enhanced starch metabolism and } \\
\text { high respiration rate }\end{array}$ & Hussain et al. ${ }^{57}$ \\
\hline $\begin{array}{l}\text { Triticum aestivum L. } \\
\text { cv. Kohistan-97 and } \\
\text { cv. Pasban-90/Wheat }\end{array}$ & 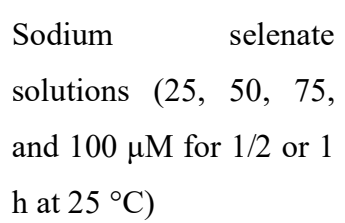 & Drought stress & $\begin{array}{l}\text { No germination } \\
\text { were recorded }\end{array}$ & $\begin{array}{l}\text { Increased root length, dry matter, } \\
\text { and the biomass of plants; total } \\
\text { sugar content and total free amino } \\
\text { acids were enhanced }\end{array}$ & Nawaz et al. ${ }^{59}$ \\
\hline
\end{tabular}




\section{Hormopriming}

\begin{tabular}{|c|c|c|c|c|c|}
\hline $\begin{array}{l}\text { Avena sativa L. cv. } \\
\text { NDO-2, UPO-212 } \\
\text { and UPO-94/Oat }\end{array}$ & $\begin{array}{l}\text { Exogenous } \mathrm{GA}_{3} \text { at }(100 \\
\text { and } 150 \mathrm{ppm})\end{array}$ & $\begin{array}{l}\text { Salinity stress }(25,50,75 \\
\text { and } 100 \mathrm{mM} \text { of } \mathrm{NaCl})\end{array}$ & $\begin{array}{l}\text { Improved germination and } \\
\text { seedling growth }\end{array}$ & $\begin{array}{l}\text { Enhanced shoot and root length, as } \\
\text { well as the total fresh and dry } \\
\text { weight, tissue water content and } \\
\text { vigor index of plants }\end{array}$ & Chauhan et al. ${ }^{164}$ \\
\hline $\begin{array}{l}\text { Cucumis sativus } \\
\text { L./Cucumber }\end{array}$ & $\begin{array}{l}\text { 3-epibrassinolide }(1,5 \\
\text { and } 10 \mu \mathrm{M})\end{array}$ & $\begin{array}{l}\text { Cadmium stress: } 2.5 \mathrm{mM} \\
\text { Cd solution }\left(\mathrm{CdCl}_{2}\right)\end{array}$ & $\begin{array}{l}\text { Mitigated the Cd stress during } \\
\text { germination and seedling } \\
\text { growth }\end{array}$ & $\begin{array}{l}\text { Enhancement were detected in root } \\
\text { fresh weight, shoot fresh weight, } \\
\text { root dry weight and shoot dry } \\
\text { weight; and phytohormones (auxin } \\
\text { and ethylene biosynthesis), } \\
\text { antioxidant activities (SOD, CAT } \\
\text { and } A P X) \text { and genes expression } \\
\left(C S \text {-ERS and } C_{S} A C O 1 \text { ) were higher }\right. \\
\text { in cucumber plants under Cd stress }\end{array}$ & Shah et al. ${ }^{165}$ \\
\hline $\begin{array}{l}\text { Oryza sativa L. cv. } \\
\text { Huanghuazhan and } \\
\text { cv. Yangliangyou- } \\
\text { 6/Rice }\end{array}$ & $\begin{array}{l}\text { Salicylic acid (100 mg } \\
\left.\mathrm{L}^{-1}\right)\end{array}$ & Chilling stress $\left(<10^{\circ} \mathrm{C}\right)$ & Enhanced seed germination & $\begin{array}{l}\text { Increased the root length, shoot } \\
\text { length, root fresh weight and shoot } \\
\text { fresh weight; increased } \alpha \text {-amylase } \\
\text { activity and total soluble sugar } \\
\text { contents }\end{array}$ & Wang et al. ${ }^{70}$ \\
\hline $\begin{array}{l}\text { Oryza sativa L. cv. IR } \\
\text { 20, IR 50, IR 64, ASD } \\
\text { 16, ASD } 19 \text { and ADT }\end{array}$ & $\begin{array}{l}\text { Methyl salicylate }(0,25 \text {, } \\
50,75 \text { and } 100, \mathrm{mg} / \mathrm{L})\end{array}$ & $\begin{array}{l}\text { Phytopathogen stress } \\
\text { (Xanthomonas oryzae) }\end{array}$ & $\begin{array}{l}\text { Increased uniform emergence } \\
\text { and early growth stages }\end{array}$ & $\begin{array}{l}\text { Enhanced root and shoot length and } \\
\text { biomass, improved phytopathogen } \\
\text { resistance }\end{array}$ & Kalaivani et al. ${ }^{166}$ \\
\hline
\end{tabular}


Thymus $\mathrm{L}^{-1}$ ), jasmonate $\left(100 \mathrm{mg}\right.$ and $30 \mathrm{mg} \mathrm{L}^{-1}$

$\left.\mathrm{L}^{-1}\right)$

Triticum aestivum L. Salicylic acid $\left(125,250\right.$, Salinity stress $\left(10 \mathrm{dS} \mathrm{m}^{-1}\right.$ (cv. Millat- 375 , and $500 \mathrm{ppm}$

2011)/Wheat

Zea mays L. cv. Methyl CM451 NARC/Maiz

\section{(Me} $20 \quad \mu \mathrm{M}) \quad \mathrm{or}$

Drought-induced oxidative and osmotic stress

No germination were recorded

salicylic acid (SA: 2

$\mathrm{mM}$ ) for $18 \mathrm{~h}$; combined

$10 \mu \mathrm{M}$ MeJA $+1 \mathrm{mM}$

SA; hydropriming as control

No germination vulgaris Salicylic acid $(100 \mathrm{mg}$

germination Increased growth attributes, as well Moori as antioxidant enzyme activity, Ahmadiproline content, and reduced leaf Lahijani $^{67}$ MDA content responses Better starch metabolism enhanced Hussain et al. ${ }^{69}$ the activities of antioxidant enzymes and reduced the lipid peroxidation rate, promoting stress tolerance and vigorous growth of plants

Improved the physiological and Tayyab et al. ${ }^{68}$ biochemical attributes; increased the antioxidant enzyme activities and showed high potential to drought tolerance

\section{Nanopriming}

Pennisetum glaucum Silver nanoparticles $(0, \quad$ Salinity stress $(0,120$ and Improved

\section{L./Pearl millet}

$$
10,20,30 \mathrm{mM} \text { ) }
$$

$150 \mathrm{mM} \mathrm{NaCl})$

performance

germination

Enhanced growth attributes and antioxidant activities

No germination were recorded
Plant traits were increased, as well Rizwan et al. ${ }^{167}$ as the plant productivity; enhanced photosynthesis response; reduced 
nanoparticles $(0,5,10$,

15 , and $20 \mathrm{mg} \mathrm{L}^{-1}$ )

\begin{abstract}
Zea mays L. CS- Titanium nanoparticles $\quad(40, \quad 60 \quad \mathrm{NaCl})$
\end{abstract} and $80 \mathrm{ppm}$ for $24 \mathrm{~h}$ )
(200 mM Enhanced

percentage and seedling vigor indexes the electrolyte leakage, and enhanced the $S O D$ and $P O D$ activities

germination Mitigated the damage under salt Shah et al. ${ }^{168}$ stress conditions by enhancing antioxidant activities, improved crop development

\section{Matrix priming}

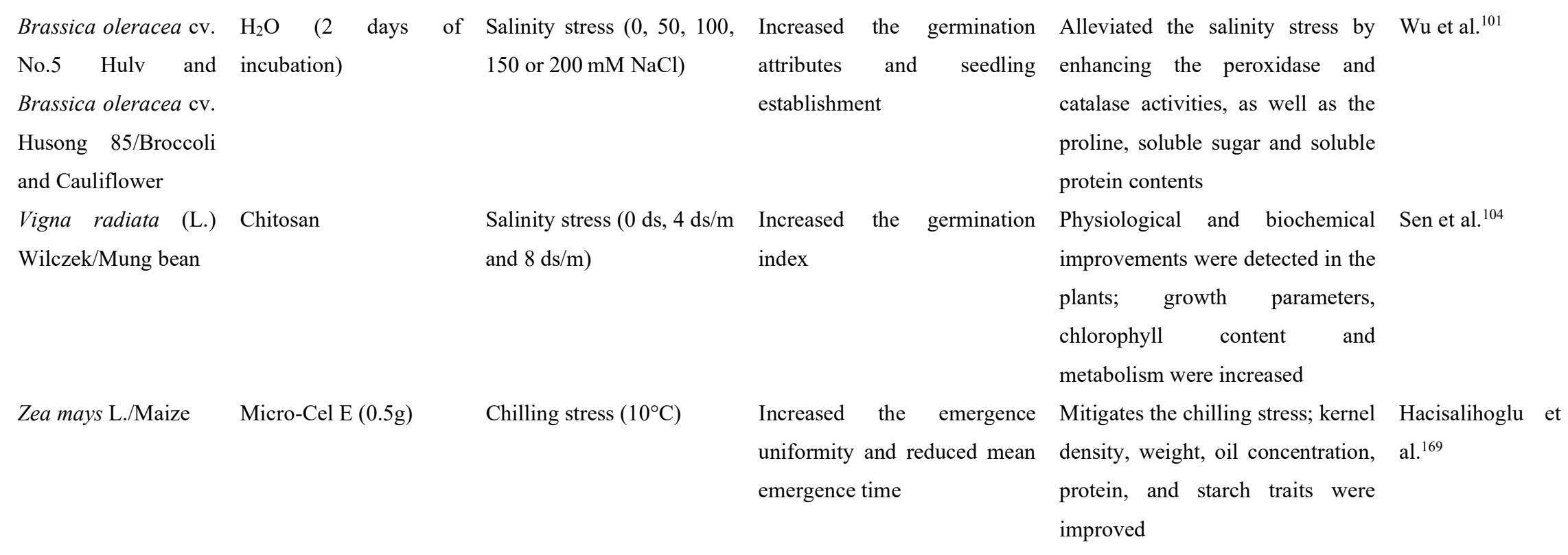




\section{Biopriming}

\begin{tabular}{|c|c|c|c|c|c|}
\hline $\begin{array}{l}\text { Raphanus sativus L. } \\
\text { cv. 'Antep', 'Beyaz', } \\
\text { and 'Siyah'/Radish }\end{array}$ & $\begin{array}{l}\text { Agrobacterium rubi, } \\
\text { Burkholderia gladii, } \\
\text { Pseudomonas putida, } \\
\text { Bacillus subtilis, and } \\
\text { Bacillus megaterium } \\
\text { strain }\end{array}$ & $\begin{array}{l}\text { Salinity stress }(0,2,4,6 \text {, } \\
\left.\text { and } 8 \mathrm{~g} \mathrm{~L}^{-1} \text { of } \mathrm{NaCl}\right)\end{array}$ & $\begin{array}{l}\text { Improved the germination } \\
\text { percentage and rate }\end{array}$ & $\begin{array}{l}\text { Mitigation of salinity stress was } \\
\text { higher depending on the } \\
\text { biopriming strain }\end{array}$ & Kaymak et al. ${ }^{170}$ \\
\hline $\begin{array}{l}\text { Triticum aestivum } \\
\text { L./Wheat }\end{array}$ & $\begin{array}{l}\text { Trichoderma harzianum } \\
\text { strain }\end{array}$ & Drought stress & $\begin{array}{l}\text { No germination responses } \\
\text { were recorded }\end{array}$ & $\begin{array}{l}\text { Increased root vigor and shoot } \\
\text { growth; enhanced drought } \\
\text { tolerance by decreasing MDA and } \\
\text { hydrogen peroxide, and an } \\
\text { increasing in total phenolic }\end{array}$ & Shukla et al. ${ }^{115}$ \\
\hline $\begin{array}{l}\text { Triticum aestivum L. } \\
\text { cv. Sids } 1, \text { cv. Stava } \\
\text { and cv. Olivin/Wheat }\end{array}$ & Rhizosphere Bacteria & Drought stress & Enhanced the germination rate & $\begin{array}{l}\text { Increased the plant parameters, } \\
\text { biomass production and } \\
\text { photosynthesis }\end{array}$ & Timmusk et al. ${ }^{105}$ \\
\hline Zea mays L./Maize & $\begin{array}{l}\text { Pseudomonas } \\
\text { geniculate }\end{array}$ & $\begin{array}{l}\text { Salinity stress }(150 \mathrm{mM} \text { of } \\
\mathrm{NaCl})\end{array}$ & $\begin{array}{l}\text { No germination responses } \\
\text { were recorded }\end{array}$ & $\begin{array}{l}\text { Significant increase of antioxidant } \\
\text { enzymes, chlorophyll and } \\
\text { carotenoids content; and increased } \\
\text { proline content and soluble sugar }\end{array}$ & Singh et al. ${ }^{126}$ \\
\hline
\end{tabular}

\section{Physical priming}

Brassica napus L. cv. Cold plasma $(100 \mathrm{~W})$

Zhongshuang 7 , cv.

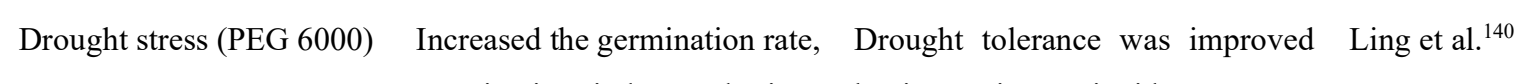
germination index and vigor by improving antioxidant enzyme 
Zhongshuang

11/Oilseed rape

Cicer arietinum Low temperature $\left(5^{\circ} \mathrm{C} \pm\right.$ Cold-stress $\left(15 / 8{ }^{\circ} \mathrm{C}\right)$,

L./Chickpea $\quad 1{ }^{\circ} \mathrm{C}$ for 30 days)

Solanum

lycopersicum/Tomato

Cold plasma (1 min, 5 Drought stress (PEG 6000) Improved

efficiency seedlings

Ralstonia solanacearum (bacterial wilt)

lycopersicum L. cv.

Shanghai $\quad 906$

(susceptible to

bacterial

wilt)/Tomato

Triticum

aestivum

L./Wheat

Cold plasma $\left(\mathrm{Ar} / \mathrm{O}_{2}\right.$ and Cadmium contamination Ar/Air) control min, and $10 \mathrm{~min}$ )

Cold plasma $(80 \mathrm{~W})$ index, and improved the dry activities, increasing osmoticweight of shoot and root, adjustment products, and reducing length of shoot and root and lipid peroxidation

lateral root number of seedling

Pollen germination increased Increased pod number and seed Thakur et al. ${ }^{135}$

to $60 \%$ in relation to the weight; reproductive function

improved by increased the sucrose concentration in the leaves along with enhanced anti-oxidative capacity and osmo-protectants' production

germination Drought stress-tolerance potential Adhikari et al. ${ }^{133}$

Increased both germination and plant growth

rowth of was detected by enhancing antioxidants, phytohormone and gene expression

Increased the activities of Jiang et al. ${ }^{137}$ antioxidant enzymes; improved the resistance to $R$. solanacearum; enhanced the dry weight of tomato

No germination responses Seeds showed considerable Kabir et al. ${ }^{171}$ were recorded. However, the progress in morphology and total seed coat became eroded and chlorophyll synthesis; significant chapped, and the $\mathrm{pH}$ of the decrease in root and shoot $\mathrm{Cd}$ concentration were detected, and 
seeds was significantly reduced expression of $\mathrm{Cd}$

reduced by plasma treatment transporters in the root (TaLCTI and TaHMA2), as well as upregulation of antioxidant enzymes $(S O D$ and $C A T)$ were detected

Triticum aestivum L. Heat-shock $\left(40^{\circ} \mathrm{C}\right.$ for 4 Heat stress (day/night Physiological and biochemical Alleviated losses of kernel weight Zhang et al. ${ }^{130}$

cv. Yangmai h)

16/Winter wheat temperature of $35 / 27^{\circ} \mathrm{C}$ )

activities improved during and grain yield by enhanced antioxidant and photosynthesis capacity; and modifications of expressions of the stress-related genes

\section{Hybrid priming}

\begin{tabular}{|c|c|c|c|c|c|}
\hline $\begin{array}{l}\text { Brassica oleracea L. } \\
\text { var. Italica/Broccoli }\end{array}$ & $\begin{array}{l}\mathrm{KCl}(50 \mathrm{mM})+\text { methyl } \\
\text { jasmonate }(25 \mu \mathrm{M})\end{array}$ & $\begin{array}{l}\text { Salinity level }(150 \mathrm{mM} \\
\mathrm{NaCl})\end{array}$ & $\begin{array}{l}\text { Improved the uniform } \\
\text { germination }\end{array}$ & $\begin{array}{l}\text { Increased plant growth and } \\
\text { counteracted salinity; provided a } \\
\text { positive response for osmotic and } \\
\text { water potentials, root hydraulic } \\
\text { conductivity, and glucosinolate } \\
\text { contents }\end{array}$ & Hassini et al. ${ }^{158}$ \\
\hline $\begin{array}{l}\text { Ceratotheca } \\
\text { (Bernh.) }\end{array}$ & $\begin{array}{l}\text { Smoke-water } \quad(1: 500 \\
\mathrm{v} / \mathrm{v})+ \text { synthesized } \\
\text { smoke-compound }\end{array}$ & $\begin{array}{l}\text { Low temperatures (10 or } \\
\left.15{ }^{\circ} \mathrm{C}\right) \text {, low osmotic } \\
\text { potential (PEG } 6000(0 ;-\end{array}$ & $\begin{array}{l}\text { Priming treatments stimulated } \\
\text { germination and improved } \\
\text { seedling grown }\end{array}$ & $\begin{array}{l}\text { Alleviated abiotic stressors during } \\
\text { seed germination and plant growth }\end{array}$ & Masondo et al. ${ }^{149}$ \\
\hline
\end{tabular}




\begin{tabular}{|c|c|c|c|c|c|}
\hline $\begin{array}{l}\text { Hook.f./Wild } \\
\text { foxglove }\end{array}$ & $\begin{array}{l}\text { karrikinolide }\left(10^{-6} \mathrm{M}\right) \text {, } \\
\text { Kelpak } \quad(0.4 \%) \text {, } \\
\text { phloroglucinol } \\
\text { (benzene-1,3,5-triol) }\end{array}$ & $\begin{array}{l}0.05 ;-0.15 ;-0.30 ; \quad-0.49 \\
\mathrm{MPa}) \text { and salinity stress }(0 ; \\
5 ; 15 ; 25 ; 50 \mathrm{mM} \text { of } \mathrm{NaCl})\end{array}$ & & & \\
\hline $\begin{array}{l}\text { Helianthus annuus L. } \\
\text { cv. } \\
\text { Wielkopolski/Sunflo } \\
\text { wer }\end{array}$ & $\begin{array}{l}\text { 24-epibrassinolide }\left(10^{-6} \text {, }\right. \\
\left.10^{-8} \text { and } 10^{-10} \mathrm{M}\right) \text {, } \\
\text { salicylic acid }\left(10^{-2}, 10^{-3}\right. \\
\left.\text { and } 10^{-4} \mathrm{M}\right) \text { and } \\
\text { jasmonic acid }\left(10^{-2}, 10^{-3}\right. \\
\left.\text { and } 10^{-4} \mathrm{M}\right) \text { followed by } \\
\text { short-term heat shock } \\
\left(45^{\circ} \mathrm{C}, 2 \mathrm{~h}\right)\end{array}$ & Chilling stress & $\begin{array}{l}\text { No germination responses } \\
\text { were recorded }\end{array}$ & $\begin{array}{l}\text { Reduced inhibition of roots as well } \\
\text { as lateral roots and plants } \\
\text { development by allowing the } \\
\text { germinating seeds to recover from } \\
\text { the growth-inhibiting effects of } \\
\text { chilling; increased resistance to } \\
\text { chilling stress via improving } \\
\text { catalase activity and sugars } \\
\text { metabolism }\end{array}$ & $\begin{array}{l}\text { Górnik and } \\
\text { Lahuta }^{151}\end{array}$ \\
\hline $\begin{array}{l}\text { Silybum } \\
\text { (L.) } \\
\text { thistle }\end{array}$ & $\begin{array}{l}\mathrm{H}_{2} \mathrm{O}_{2}(0,80,160,240 \mu \mathrm{M} \\
\text { for } 8 \mathrm{~h})+ \text { magnetic field } \\
(0,10,20,30 \mathrm{~min})\end{array}$ & $\begin{array}{l}\text { Salinity stress } \quad \text { (EC: } 50 \\
\mathrm{Ms} / \mathrm{cm})\end{array}$ & $\begin{array}{l}\text { Increased growth of seedlings } \\
\text { in the early stages }\end{array}$ & $\begin{array}{l}\text { Increased salt-tolerance and } \\
\text { improved physiological attributes } \\
\text { by alleviating the oxidative damage }\end{array}$ & Migahid et al. ${ }^{172}$ \\
\hline Zea mays L./Maize & $\begin{array}{l}\text { Salicylic acid }(0.5 \mathrm{mM}) \\
+\mathrm{H}_{2} \mathrm{O}_{2}(50 \mathrm{mM})\end{array}$ & Chilling stress $\left(13{ }^{\circ} \mathrm{C}\right)$ & $\begin{array}{l}\text { Improvements in the } \\
\text { germination indexes and } \\
\text { seedling growth }\end{array}$ & $\begin{array}{l}\text { Enhanced plant quality and plant } \\
\text { establishment; promoted hormone } \\
\text { metabolism and signal } \\
\text { transduction, and enhanced energy } \\
\text { supply and increased antioxidant } \\
\text { enzyme activities }\end{array}$ & Li et al. ${ }^{21}$ \\
\hline
\end{tabular}


Author Contributions: D.G., S.Z. and Y.Z. conceived and designed the study. D.G., S.Z., S.A. and Y.Z. wrote the manuscript. L.C.M. and D.H. wrote the manuscript and performed the critical review. All authors approved the final manuscript.

Funding: Shanghai Agriculture Applied Technology Development Program, China [Grant No. (2019) 2-3].

Acknowledgments: Special thanks are due to the Shanghai Agriculture Applied Technology Development Program for the financial support.

Conflicts of Interests: All authors declare that they have no conflict of interests, competitors and/or financial in relation to the publication of this scientific paper.

\section{References}

1. FAO. Food and Agriculture Organization of the United Nations. http://www.fao.org/home/en/ (2019).

2. Butcher, K., Wick, A. F., Desutter, T., Chatterjee, A. \& Harmon, J. Soil salinity: A threat to global food security. Agron. J. 108, 2189-2200 (2016).

3. FAO. Food and Agriculture Organization of the United Nations. http://www.fao.org/3/I8656EN/i8656en.pdf (2018).

4. Shu, K., Liu, X. D., Xie, Q. \& He, Z. H. Two Faces of One Seed: Hormonal Regulation of Dormancy and Germination. Mol. Plant 9, 34-45 (2016).

5. Miransari, M. \& Smith, D. L. Plant hormones and seed germination. Environ. Exp. Bot. 99, 110-121 (2014).

6. Nakaune, M. et al. Molecular and physiological dissection of enhanced seed germination using short-term low-concentration salt seed priming in tomato. Plant Physiol. Biochem. 52, 28-37 (2012).

7. Yang, R. et al. Hormone profiling and transcription analysis reveal a major role ofABA in tomato salt tolerance. Plant Physiol. Biochem. 77, 23-34 (2014).

8. Puértolas, J., Albacete, A. \& Dodd, I. C. Irrigation frequency transiently alters whole plant gas exchange, water and hormone status, but irrigation volume determines cumulative growth in two herbaceous crops. Environ. Exp. Bot. 176, (2020).

9. Wang, S. et al. Increasing the agricultural, environmental and economic benefits of farming based on suitable crop rotations and optimum fertilizer applications. F. Crop. Res. 240, 78-85 (2019).

10. Tian, J., Xu, G. \& Yuan, M. Towards Engineering Broad-Spectrum Disease-Resistant Crops. Trends Plant Sci. 25, 424-427 (2020).

11. Chen, K. \& Arora, R. Priming memory invokes seed stress-tolerance. Environ. Exp. Bot. 94, 33-45 (2013).

12. Jisha, K. C., Vijayakumari, K. \& Puthur, J. T. Seed priming for abiotic stress tolerance: An overview. Acta Physiol. Plant. 35, 1381-1396 (2013).

13. Ibrahim, E. A. Seed priming to alleviate salinity stress in germinating seeds. J. Plant Physiol. 192, 38-46 (2016).

14. Zhao, Y., Hu, M., Gao, Z., Chen, X. \& Huang, D. Biological mechanisms of a novel hydro-electro hybrid priming recovers potential vigor of onion seeds. Environ. Exp. Bot. 150, 260-271 (2018).

15. Mondal, S. \& Bose, B. Impact of micronutrient seed priming on germination, growth, development, nutritional status and yield aspects of plants. J. Plant Nutr. 42, 2577-2599 (2019).

16. Rifna, E. J., Ratish Ramanan, K. \& Mahendran, R. Emerging technology applications for improving seed germination. Trends Food Sci. Technol. 86, 95-108 (2019).

17. Kubala, S. et al. Deciphering priming-induced improvement of rapeseed (Brassica napus L.) germination through an integrated transcriptomic and proteomic approach. Plant Sci. 231, 94-113 (2015). 
18. Chen, H. H., Chen, Y. K. \& Chang, H. C. Evaluation of physicochemical properties of plasma treated brown rice. Food Chem. 135, 74-79 (2012).

19. WANG, X., LIU, F. lai \& JIANG, D. Priming: A promising strategy for crop production in response to future climate. J. Integr. Agric. 16, 2709-2716 (2017).

20. Dawood, M. G. Stimulating plant tolerance against abiotic stress through seed priming. Adv. Seed Priming 147-183 (2018) doi:10.1007/978-981-13-0032-5_10.

21. Li, Z. et al. The synergistic priming effect of exogenous salicylic acid and $\mathrm{H} 2 \mathrm{O} 2$ on chilling tolerance enhancement during maize (Zea mays L.) seed germination. Front. Plant Sci. 8, (2017).

22. Yang, R. et al. The mechanism underlying fast germination of tomato cultivar LA2711. Plant Sci. 238, 241-250 (2015).

23. Marthandan, V. et al. Seed priming: A feasible strategy to enhance drought tolerance in crop plants. Int. J. Mol. Sci. 21, 1-23 (2020).

24. Paparella, S. et al. Seed priming: state of the art and new perspectives. Plant Cell Rep. 34, 1281-1293 (2015).

25. Hussain, S. et al. Comparative transcriptional profiling of primed and non-primed rice seedlings under submergence stress. Front. Plant Sci. 7, (2016).

26. Hubbard, M., Germida, J. \& Vujanovic, V. Fungal endophytes improve wheat seed germination under heat and drought stress. Botany 90, 137-149 (2012).

27. Blunk, S. et al. Seed priming enhances early growth and improves area of soil exploration by roots. Environ. Exp. Bot. 158, 1-11 (2019).

28. Hatfield, J. L. \& Prueger, J. H. Temperature extremes: Effect on plant growth and development. Weather Clim. Extrem. 10, 4-10 (2015).

29. Łabanowska, M., Kurdziel, M., Filek, M. \& Wesełucha-Birczyńska, A. The impact of biochemical composition and nature of paramagnetic species in grains on stress tolerance of oat cultivars. J. Plant Physiol. 199, 52-66 (2016).

30. King, T. et al. Food safety for food security: Relationship between global megatrends and developments in food safety. Trends Food Sci. Technol. 68, 160-175 (2017).

31. Płażek, A. et al. Seed hydropriming and smoke water significantly improve lowtemperature germination of lupinus angustifolius L. Int. J. Mol. Sci. 19, (2018).

32. Mondal, S. et al. Responses of AG1 and AG2 QTL introgression lines and seed pretreatment on growth and physiological processes during anaerobic germination of rice under flooding. Sci. Rep. 10, (2020).

33. Kaya, M. D., Okçu, G., Atak, M., Çikili, Y. \& Kolsarici, Ö. Seed treatments to overcome salt and drought stress during germination in sunflower (Helianthus annuus L.). Eur. J. Agron. 24, 291-295 (2006).

34. Forti, C. et al. Hydropriming and biopriming improve medicago truncatula seed germination and upregulate dna repair and antioxidant genes. Genes (Basel). 11, (2020).

35. Farooq, M., Wahid, A., Kobayashi, N., Fujita, D. \& Basra, S. M. A. Plant drought stress: Effects, mechanisms and management. Agron. Sustain. Dev. 29, 185-212 (2009).

36. Baxter, A., Mittler, R. \& Suzuki, N. ROS as key players in plant stress signalling. J. Exp. Bot. 65, 1229-1240 (2014).

37. Ella, E. S., Dionisio-Sese, M. L. \& Ismail, A. M. Seed pre-treatment in rice reduces damage, enhances carbohydrate mobilization and improves emergence and seedling establishment under flooded conditions. AoB Plants 11, (2011).

38. Mouradi, M. et al. Seed osmopriming improves plant growth, nodulation, chlorophyll fluorescence and nutrient uptake in alfalfa (Medicago sativa L.) - rhizobia symbiosis under drought stress. Sci. Hortic. (Amsterdam). 213, 232-242 (2016).

39. Ferreira Ribas, A. et al. Regulation of $\alpha$-expansins genes in Arabidopsis thaliana seeds during post-osmopriming germination. Physiol. Mol. Biol. Plants 25, 511-522 (2019).

40. Li, H. et al. Salt priming protects photosynthetic electron transport against lowtemperature-induced damage in wheat. Sensors (Switzerland) 20, (2020).

41. Kubala, S. et al. Enhanced expression of the proline synthesis gene P5CSA in relation 
to seed osmopriming improvement of Brassica napus germination under salinity stress. J. Plant Physiol. 183, 1-12 (2015).

42. Litalien, A. \& Zeeb, B. Curing the earth: A review of anthropogenic soil salinization and plant-based strategies for sustainable mitigation. Sci. Total Environ. 698, (2020).

43. Tabassum, T. et al. Terminal drought and seed priming improves drought tolerance in wheat. Physiol. Mol. Biol. Plants 24, 845-856 (2018).

44. Chen, K. \& Arora, R. Priming memory invokes seed stress-tolerance. Environ. Exp. Bot. 94, 33-45 (2013).

45. Choi, D. W. \& Close, T. J. A newly identified barley gene, Dhn12, encoding a YSK2 DHN, is located on chromosome $6 \mathrm{H}$ and has embryo-specific expression. Theor. Appl. Genet. 100, 1274-1278 (2000).

46. Chen, K., Fessehaie, A. \& Arora, R. Dehydrin metabolism is altered during seed osmopriming and subsequent germination under chilling and desiccation in Spinacia oleracea L. cv. Bloomsdale: Possible role in stress tolerance. Plant Sci. 183, 27-36 (2012).

47. Munns, R. \& Gilliham, M. Salinity tolerance of crops - what is the cost? New Phytol. 208, 668-673 (2015).

48. Kopittke, P. M., Menzies, N. W., Wang, P., McKenna, B. A. \& Lombi, E. Soil and the intensification of agriculture for global food security. Environ. Int. 132, (2019).

49. Saadat, S. \& Homaee, M. Modeling sorghum response to irrigation water salinity at early growth stage. Agric. Water Manag. 152, 119-124 (2015).

50. Feghhenabi, F., Hadi, H., Khodaverdiloo, H. \& van Genuchten, M. T. Seed priming alleviated salinity stress during germination and emergence of wheat (Triticum aestivum L.). Agric. Water Manag. 231, (2020).

51. Li, X. et al. Induction of chilling tolerance in wheat during germination by pre-soaking seed with nitric oxide and gibberellin. Plant Growth Regul. 71, 31-40 (2013).

52. Li, X. et al. Cold priming drives the sub-cellular antioxidant systems to protect photosynthetic electron transport against subsequent low temperature stress in winter wheat. Plant Physiol. Biochem. 82, 34-43 (2014).

53. Weigand, C. Wheat Import Projections Towards 2050. (2011).

54. Bhardwaj, J., Anand, A., Pandita, V. K. \& Nagarajan, S. Pulsed magnetic field improves seed quality of aged green pea seeds by homeostasis of free radical content. J. Food Sci. Technol. 53, 3969-3977 (2016).

55. Zhang, F. et al. Seed priming with polyethylene glycol induces physiological changes in sorghum (Sorghum bicolor L. moench) seedlings under suboptimal soil moisture environments. PLoS One 10, (2015).

56. Moulick, D., Ghosh, D. \& Chandra Santra, S. Evaluation of effectiveness of seed priming with selenium in rice during germination under arsenic stress. Plant Physiol. Biochem. 109, 571-578 (2016).

57. Hussain, S., Khan, F., Hussain, H. A. \& Nie, L. Physiological and biochemical mechanisms of seed priming-induced chilling tolerance in rice cultivars. Front. Plant Sci. 7, (2016).

58. Hozayn, M., Abd-Elmonem, A. A. \& Samaha, G. M. The physiological effect of presoaking with tryptophan on sugar beet (Beta vulgaris L.) productivity under different levels of salinity stresses. Bull. Natl. Res. Cent. 44, (2020).

59. Nawaz, F., Ashraf, M. Y., Ahmad, R. \& Waraich, E. A. Selenium (Se) seed priming induced growth and biochemical changes in wheat under water deficit conditions. Biol. Trace Elem. Res. 151, 284-293 (2013).

60. Savvides, A., Ali, S., Tester, M. \& Fotopoulos, V. Chemical Priming of Plants Against Multiple Abiotic Stresses: Mission Possible? Trends Plant Sci. 21, 329-340 (2016).

61. Hussain, S. et al. Benefits of rice seed priming are offset permanently by prolonged storage and the storage conditions. Sci. Rep. 5, 8101 (2015).

62. Valivand, M., Amooaghaie, R. \& Ahadi, A. Seed priming with $\mathrm{H} 2 \mathrm{~S}$ and $\mathrm{Ca} 2+$ trigger 
signal memory that induces cross-adaptation against nickel stress in zucchini seedlings. Plant Physiol. Biochem. 143, 286-298 (2019).

63. Verma, V., Ravindran, P. \& Kumar, P. P. Plant hormone-mediated regulation of stress responses. BMC Plant Biol. 16, (2016).

64. Seo, J. S. et al. OsbHLH148, a basic helix-loop-helix protein, interacts with OsJAZ proteins in a jasmonate signaling pathway leading to drought tolerance in rice. Plant $J$. 65, 907-921 (2011).

65. Waadt, R. Phytohormone signaling mechanisms and genetic methods for their modulation and detection. Curr. Opin. Plant Biol. 57, 31-40 (2020).

66. Madany, M. M. Y. et al. Hormonal seed-priming improves tomato resistance against broomrape infection. J. Plant Physiol. 250, (2020).

67. Moori, S. \& Ahmadi-Lahijani, M. J. Hormopriming instigates defense mechanisms in Thyme (Thymus vulgaris L.) seeds under cadmium stress. J. Appl. Res. Med. Aromat. Plants 19, (2020).

68. Tayyab, N. et al. Combined seed and foliar pre-treatments with exogenous methyl jasmonate and salicylic acid mitigate drought-induced stress in maize. PLoS One 15, (2020).

69. Hussain, S., Khaliq, A., Tanveer, M., Matloob, A. \& Hussain, H. A. Aspirin priming circumvents the salinity-induced effects on wheat emergence and seedling growth by regulating starch metabolism and antioxidant enzyme activities. Acta Physiol. Plant. 40, (2018).

70. Wang, W. et al. Effects of pre-sowing seed treatments on establishment of dry directseeded early rice under chilling stress. AoB Plants 8, (2016).

71. Guo, Z., Ou, W., Lu, S. \& Zhong, Q. Differential responses of antioxidative system to chilling and drought in four rice cultivars differing in sensitivity. Plant Physiol. Biochem. 44, 828-836 (2006).

72. Gill, S. S. \& Tuteja, N. Reactive oxygen species and antioxidant machinery in abiotic stress tolerance in crop plants. Plant Physiol. Biochem. 48, 909-930 (2010).

73. Shu, D. F., Wang, L. Y., Duan, M., Deng, Y. S. \& Meng, Q. W. Antisense-mediated depletion of tomato chloroplast glutathione reductase enhances susceptibility to chilling stress. Plant Physiol. Biochem. 49, 1228-1237 (2011).

74. Oliver, S. N., Dennis, E. S. \& Dolferus, R. ABA regulates apoplastic sugar transport and is a potential signal for cold-induced pollen sterility in rice. Plant Cell Physiol. 48, 13191330 (2007).

75. Ruelland, E. et al. Cold signalling and cold acclimation in plants. Adv Bot Res 49, 35150 (2009).

76. Pál, M., Gondor, O. \& Janda, T. Role of salicylic acid in acclimation to low temperature. Acta Agron. Hungarica 61, 161-172 (2013).

77. Varier, A., Vari, A. K. \& Dadlani, M. The subcellular basis of seed priming. Curr. Sci. 99, 450-456 (2010).

78. Samota, M. K. et al. Elicitor-induced biochemical and molecular manifestations to improve drought tolerance in rice (Oryza sativa L.) through seed-priming. Front. Plant Sci. 8, (2017).

79. Sedghi, M., Nemati, A. \& Esmaielpour, B. Sedghi2010. 22, 130-139 (2010).

80. Younesi, O. \& Moradi, A. Effect of priming of seeds of Medicago sativa "BAMI" with gibberellic acid on germination, seedlings growth and antioxidant enzymes activity under salinity stress. J. Hortic. Res. 22, 167-174 (2014).

81. Gomez, A. et al. Effects of nano-enabled agricultural strategies on food quality: Current knowledge and future research needs. J. Hazard. Mater. 401, (2021).

82. Nandhini, M. et al. Biofabricated zinc oxide nanoparticles as an eco-friendly alternative for growth promotion and management of downy mildew of pearl millet. Crop Prot. 121, 103-112 (2019).

83. Sharma, G. et al. Chitosan nanofertilizer to foster source activity in maize. Int. J. Biol. 
Macromol. 145, 226-234 (2020).

84. Moreno, A., Jordana, A., Grillo, R., Fraceto, L. F. \& Jaime, C. A study on the molecular existing interactions in nanoherbicides: A chitooligosaccharide/tripolyphosphate loaded with paraquat case. Colloids Surfaces A Physicochem. Eng. Asp. 562, 220-228 (2019).

85. Simonin, M. et al. Plant and Microbial Responses to Repeated $\mathrm{Cu}(\mathrm{OH}) 2$ Nanopesticide Exposures Under Different Fertilization Levels in an Agro-Ecosystem. Front. Microbiol. 9, (2018).

86. Yadav, S. K. et al. Factors affecting the fate, transport, bioavailability and toxicity of nanoparticles in the agroecosystem. Emerg. trends agri-nanotechnology Fundam. Appl. Asp. 118-134 (2018) doi:10.1079/9781786391445.0118.

87. Singh, V. K. et al. Seed priming: state of the art and new perspectives in the era of climate change. Climate Change and Soil Interactions (LTD, 2020). doi:10.1016/b9780-12-818032-7.00006-0.

88. Guan, Y. J., Hu, J., Wang, X. J. \& Shao, C. X. Seed priming with chitosan improves maize germination and seedling growth in relation to physiological changes under low temperature stress. J. Zhejiang Univ. Sci. B 10, 427-433 (2009).

89. Pereira, A. do E. S., Oliveira, H. C. \& Fraceto, L. F. Polymeric nanoparticles as an alternative for application of gibberellic acid in sustainable agriculture: a field study. Sci. Rep. 9, (2019).

90. Kalal, P. R. \& Jajoo, A. Priming with Zinc oxide nanoparticles improve germination and photosynthetic performance in wheat. Plant Physiol. Biochem. (2021) doi:10.1016/j.plaphy.2021.01.032.

91. Mahakham, W., Sarmah, A. K., Maensiri, S. \& Theerakulpisut, P. Nanopriming technology for enhancing germination and starch metabolism of aged rice seeds using phytosynthesized silver nanoparticles. Sci. Rep. 7, (2017).

92. Zari, H., Babak, P. \& Asad, R. The Effect of Priming with Nano-sliver on Agronomic Traits of Safflower Cultivars. J. Essent. Oil-Bearing Plants 18, 1148-1156 (2015).

93. Acharya, P., Jayaprakasha, G. K., Crosby, K. M., Jifon, J. L. \& Patil, B. S. NanoparticleMediated Seed Priming Improves Germination, Growth, Yield, and Quality of Watermelons (Citrullus lanatus) at multi-locations in Texas. Sci. Rep. 10, (2020).

94. Khalaki, M. A., Ghorbani, A. \& Moameri, M. Effects of silica and silver nanoparticles on seed germination traits of Thymus kotschyanus in laboratory conditions. J. Rangel. Sci. 6, 221-231 (2016).

95. Khan, I. et al. Amelioration of salt induced toxicity in pearl millet by seed priming with silver nanoparticles (AgNPs): The oxidative damage, antioxidant enzymes and ions uptake are major determinants of salt tolerant capacity. Plant Physiol. Biochem. 156, 221-232 (2020).

96. Shafiq, F., Iqbal, M., Ali, M. \& Ashraf, M. A. Fullerenol regulates oxidative stress and tissue ionic homeostasis in spring wheat to improve net-primary productivity under saltstress. Ecotoxicol. Environ. Saf. 211, (2021).

97. Maswada, H. F., Djanaguiraman, M. \& Prasad, P. V. V. Seed treatment with nano-iron (III) oxide enhances germination, seeding growth and salinity tolerance of sorghum. $J$. Agron. Crop Sci. 204, 577-587 (2018).

98. Taylor, A. G., Klein, D. E. \& Whitlow, T. H. SMP: Solid matrix priming of seeds. Sci. Hortic. (Amsterdam). 37, 1-11 (1988).

99. Lingyun, W., Dongwei, Y.\& Ming, L. Effects of solid matrix priming with Trichoderma harzianum on seed germination, seedling emergence and photosynthetic capacity of eggplant. African J. Biotechnol. 16, 699-703 (2017).

100.Sen, A. \& Puthur, J. T. Influence of different seed priming techniques on oxidative and antioxidative responses during the germination of Oryza sativa varieties. Physiol. Mol. Biol. Plants 26, 551-565 (2020).

101.Wu, L., Huo, W., Yao, D. \& Li, M. Effects of solid matrix priming (SMP)and salt stress on broccoli and cauliflower seed germination and early seedling growth. Sci. Hortic. 
(Amsterdam). 255, 161-168 (2019).

102.Pandita, V. K., Anand, A., Nagarajan, S., Seth, R. \& Sinha, S. N. Solid matrix priming improves seed emergence and crop performance in okra. Seed Sci. Technol. 38, 665$674(2010)$.

103.Waqas, M. et al. Advances in the Concept and Methods of Seed Priming. Priming Pretreat. Seeds Seedlings 11-41 (2019) doi:10.1007/978-981-13-8625-1_2.

104.Sen, S. K., Chouhan, D., Das, D., Ghosh, R. \& Mandal, P. Improvisation of salinity stress response in mung bean through solid matrix priming with normal and nano-sized chitosan. Int. J. Biol. Macromol. 145, 108-123 (2020).

105.Timmusk, S. et al. Drought-tolerance of wheat improved by rhizosphere bacteria from harsh environments: Enhanced biomass production and reduced emissions of stress volatiles. PLoS One 9, (2014).

106. Waller, F. et al. The endophytic fungus Piriformospora indica reprograms barley to saltstress tolerance, disease resistance, and higher yield. Proc. Natl. Acad. Sci. U. S. A. 102, 13386-13391 (2005).

107.Couillerot, O. et al. Comparison of prominent Azospirillum strains in AzospirillumPseudomonas- Glomus consortia for promotion of maize growth. Appl. Microbiol. Biotechnol. 97, 4639-4649 (2013).

108.Rozier, C., Gerin, F., Czarnes, S. \& Legendre, L. Biopriming of maize germination by the plant growth-promoting rhizobacterium Azospirillum lipoferum CRT1. J. Plant Physiol. 237, 111-119 (2019).

109.Rajput, R. S. et al. Seed Biopriming Through Beneficial Rhizobacteria for Mitigating Soil-Borne and Seed-Borne Diseases. 201-215 (2019) doi:10.1007/978-981-13-698657.

110.Reddy, P. P. \& Reddy, P. P. Bio-priming of Seeds. Recent Adv. Crop Prot. 83-90 (2012) doi:10.1007/978-81-322-0723-8 6.

111.Singh, H. B. Seed biopriming: A comprehensive approach towards agricultural sustainability. Indian Phytopathol. 69, 203-209 (2016).

112.Sarkar, R. K., Mukherjee, A. K. \& Chakraborty, K. Seed Priming Alleviates Stress Tolerance in Rice (Oryza sativa L.). Priming Pretreat. Seeds Seedlings 181-204 (2019) doi:10.1007/978-981-13-8625-1 9.

113.Rakshit, A., Sunita, K., Pal, S., Singh, A. \& Singh, H. B. Bio-priming Mediated Nutrient Use Efficiency of Crop Species. Nutr. Use Effic. From Basics to Adv. 181-191 (2015) doi:10.1007/978-81-322-2169-2 12.

114.Pozo, M. J. \& Azcón-Aguilar, C. Unraveling mycorrhiza-induced resistance. Curr. Opin. Plant Biol. 10, 393-398 (2007).

115.Shukla, N., Awasthi, R. P., Rawat, L. \& Kumar, J. Seed biopriming with drought tolerant isolates of Trichoderma harzianum promote growth and drought tolerance in Triticum aestivum. Ann. Appl. Biol. 166, 171-182 (2015).

116.Meena, S. K., Rakshit, A. \& Meena, V. S. Effect of seed bio-priming and N doses under varied soil type on nitrogen use efficiency (NUE) of wheat (Triticum aestivum L.) under greenhouse conditions. Biocatal. Agric. Biotechnol. 6, 68-75 (2016).

117.Mcallister, C. H., Beatty, P. H. \& Good, A. G. Engineering nitrogen use efficient crop plants: The current status. Plant Biotechnol. J. 10, 1011-1025 (2012).

118.Kumar Meena, R., Kumar Singh, R., Pal Singh, N., Kumari Meena, S. \& Singh Meena, $\mathrm{V}$. Isolation of low temperature surviving plant growth - promoting rhizobacteria (PGPR) from pea (Pisum sativum L.) and documentation of their plant growth promoting traits. Biocatal. Agric. Biotechnol. 4, 806-811 (2015).

119.Müller, H. \& Berg, G. Impact of formulation procedures on the effect of the biocontrol agent Serratia plymuthica HRO-C48 on Verticillium wilt in oilseed rape. BioControl 53, 905-916 (2008).

120.Singh, S. et al. Seed biopriming with microbial inoculant triggers local and systemic defense responses against Rhizoctonia solani causing banded leaf and sheath blight in 
maize (Zea mays 1.). Int. J. Environ. Res. Public Health 17, (2020).

121.Raj, S. N., Shetty, N. P. \& Shetty, H. S. Seed bio-priming with Pseudomonas fluorescens isolates enhances growth of pearl millet plants and induces resistance against downy mildew. Int. J. Pest Manag. 50, 41-48 (2004).

122.Bita, C. E. \& Gerats, T. Plant tolerance to high temperature in a changing environment: Scientific fundamentals and production of heat stress-tolerant crops. Front. Plant Sci. 4, (2013).

123.Sun, Q. et al. Global heat stress on health, wildfires, and agricultural crops under different levels of climate warming. Environ. Int. 128, 125-136 (2019).

124.Asseng, S. et al. Rising temperatures reduce global wheat production. Nat. Clim. Chang. 5, 143-147 (2015).

125.Serrano, N., Ling, Y., Bahieldin, A. \& Mahfouz, M. M. Thermopriming reprograms metabolic homeostasis to confer heat tolerance. Sci. Rep. 9, (2019).

126.Singh, S. et al. Seed biopriming with salt-tolerant endophytic pseudomonas geniculatamodulated biochemical responses provide ecological fitness in maize (Zea mays L.) grown in saline sodic soil. Int. J. Environ. Res. Public Health 17, (2020).

127.Dias, A. S., Semedo, J., Ramalho, J. C. \& Lidon, F. C. Bread and Durum Wheat under Heat Stress: A Comparative Study on the Photosynthetic Performance. J. Agron. Crop Sci. 197, 50-56 (2011).

128.Hilker, M. et al. Priming and memory of stress responses in organisms lacking a nervous system. Biol. Rev. 91, 1118-1133 (2016).

129.Ling, Y. et al. Thermopriming triggers splicing memory in Arabidopsis. J. Exp. Bot. 69, 2659-2675 (2018).

130.Zhang, X. et al. Physiological and transcriptional analyses of induced post-anthesis thermo-tolerance by heat-shock pretreatment on germinating seeds of winter wheat. Environ. Exp. Bot. 131, 181-189 (2016).

131.Baier, M., Bittner, A., Prescher, A. \& van Buer, J. Preparing plants for improved cold tolerance by priming. Plant Cell Environ. 42, 782-800 (2019).

132.Wang, X. et al. Multiple heat priming enhances thermo-tolerance to a later high temperature stress via improving subcellular antioxidant activities inwheat seedlings. Plant Physiol. Biochem. 74, 185-192 (2014).

133.Adhikari, B. et al. Cold plasma seed priming modulates growth, redox homeostasis and stress response by inducing reactive species in tomato (Solanum lycopersicum). Free Radic. Biol. Med. 156, 57-69 (2020).

134.Larkindale, J. \& Huang, B. Changes of lipid composition and saturation level in leaves and roots for heat-stressed and heat-acclimated creeping bentgrass (Agrostis stolonifera). Environ. Exp. Bot. 51, 57-67 (2004).

135.Thakur, A., Sharma, K. D., Siddique, K. H. M. \& Nayyar, H. Cold priming the chickpea seeds imparts reproductive cold tolerance by reprogramming the turnover of carbohydrates, osmo-protectants and redox components in leaves. Sci. Hortic. (Amsterdam). 261, (2020).

136.Lewis, S. C., King, A. D., Perkins-Kirkpatrick, S. E. \& Mitchell, D. M. Regional hotspots of temperature extremes under $1.5^{\circ} \mathrm{C}$ and $2{ }^{\circ} \mathrm{C}$ of global mean warming. Weather Clim. Extrem. 26, (2019).

137.Jiang, J. et al. Effect of seed treatment by cold plasma on the resistance of tomato to Ralstonia solanacearum (bacterial wilt). PLoS One 9, (2014).

138.Sivachandiran, L. \& Khacef, A. Enhanced seed germination and plant growth by atmospheric pressure cold air plasma: combined effect of seed and water treatment. RSC Adv. 7, 1822-1832 (2017).

139.Adhikari, B., Adhikari, M. \& Park, G. The effects of plasma on plant growth, development, and sustainability. Appl. Sci. 10, (2020).

140.Ling, L., Jiangang, L., Minchong, S., Chunlei, Z. \& Yuanhua, D. Cold plasma treatment enhances oilseed rape seed germination under drought stress. Sci. Rep. 5, (2015). 
141.Mildažienè, V. et al. Treatment of common sunflower (Helianthus annus L.) seeds with radio-frequency electromagnetic field and cold plasma induces changes in seed phytohormone balance, seedling development and leaf protein expression. Sci. Rep. 9, (2019).

142.Ghasempour, M., Iranbakhsh, A., Ebadi, M. \& Oraghi Ardebili, Z. Seed priming with cold plasma improved seedling performance, secondary metabolism, and expression of deacetylvindoline O-acetyltransferase gene in Catharanthus roseus. Contrib. to Plasma Phys. 60, (2020).

143.Seddighinia, F. S., Iranbakhsh, A., Oraghi Ardebili, Z., Nejad Satari, T. \& Soleimanpour, S. Seed Priming with Cold Plasma and Multi-walled Carbon Nanotubes Modified Growth, Tissue Differentiation, Anatomy, and Yield in Bitter Melon (Momordica charantia). J. Plant Growth Regul. 39, 87-98 (2020).

144.Li, L. et al. Improving Seed Germination and Peanut Yields by Cold Plasma Treatment. Plasma Sci. Technol. 18, 1027-1033 (2016).

145.Šerá, B., Špatenka, P., Šerý, M., Vrchotová, N. \& Hrušková, I. Influence of plasma treatment on wheat and oat germination and early growth. IEEE Trans. Plasma Sci. 38, 2963-2968 (2010).

146. Wang, X. Q. et al. Spectral characteristics of cotton seeds treated by a dielectric barrier discharge plasma. Sci. Rep. 7, (2017).

147.Khatami, S. \& Ahmadinia, A. Increased germination and growth rates of pea and Zucchini seed by FSG plasma. J. Theor. Appl. Phys. 12, 33-38 (2018).

148.Zhou, R. et al. Combined high light and heat stress induced complex response in tomato with better leaf cooling after heat priming. Plant Physiol. Biochem. 151, 1-9 (2020).

149.Masondo, N. A., Kulkarni, M. G., Finnie, J. F. \& Van Staden, J. Influence of biostimulants-seed-priming on Ceratotheca triloba germination and seedling growth under low temperatures, low osmotic potential and salinity stress. Ecotoxicol. Environ. Saf. 147, 43-48 (2018).

150.Hela, M., Zargouni, H., Tarchoune, I., Baatour, O., Nasri, N., Ben Massoud, R., Raouia, B.M., Maha, Z., Wissal, A., Jun, H., Abdelali, H., Mokhtar, L., Zeineb, L. Combined effect of hormonal priming and salt treatments on germination percentage and antioxidant activities in lettuce seedlings. African J. Biotechnol. 11, 10373-10380 (2012).

151.Górnik, K. \& Lahuta, L. B. Application of phytohormones during seed hydropriming and heat shock treatment on sunflower (Helianthus annuus L.) chilling resistance and changes in soluble carbohydrates. Acta Physiol. Plant. 39, 1-12 (2017).

152.Leong, S. Y., Burritt, D. J. \& Oey, I. Electropriming of wheatgrass seeds using pulsed electric fields enhances antioxidant metabolism and the bioprotective capacity of wheatgrass shoots. Sci. Rep. 6, (2016).

153.Maffei, M. E. Magnetic field effects on plant growth, development, and evolution. Front. Plant Sci. 5, (2014).

154.Dannehl, D. Effects of electricity on plant responses. Sci. Hortic. (Amsterdam). 234, 382-392 (2018).

155.Hussain, M., Farooq, M., Basra, S. M. A. \& Ahmad, N. Influence of seed priming techniques on the seedling establishment, yield and quality of hybrid sunflower. Int. J. Agric. Biol. 8, 14-18 (2006).

156.Garcia, D., Zhao, Y., Zhao, S., Ming, L. C. \& Huang, D. Hydroelectrostatic hybrid priming stimulates germination performance via $\mathrm{ABA}$ and GA regulation: New promising evidence for tomato gene expression. Curr. Plant Biol. 27, 100215 (2021).

157.Balfagón, D., Zandalinas, S. I. \& Gómez-Cadenas, A. High temperatures change the perspective: Integrating hormonal responses in citrus plants under co-occurring abiotic stress conditions. Physiol. Plant. 165, 183-197 (2019).

158.Hassini, I., Martinez-Ballesta, M. C., Boughanmi, N., Moreno, D. A. \& Carvajal, M. Improvement of broccoli sprouts (Brassica oleracea L. var. italica) growth and quality 
by $\mathrm{KCl}$ seed priming and methyl jasmonate under salinity stress. Sci. Hortic. (Amsterdam). 226, 141-151 (2017).

159.Lee, S. et al. Gibberellin regulates Arabidopsis seed germination via RGL2, a GAI/RGA-like gene whose expression is up-regulated following imbibition. Genes Dev. 16, 646-658 (2002).

160.Nouman, W. et al. Seed priming improves the emergence potential, growth and antioxidant system of Moringa oleifera under saline conditions. Plant Growth Regul. 73, 267-278 (2014).

161.Yan, M. Seed priming stimulate germination and early seedling growth of Chinese cabbage under drought stress. South African J. Bot. 99, 88-92 (2015).

162.Sen, A. \& Puthur, J. T. Influence of different seed priming techniques on oxidative and antioxidative responses during the germination of Oryza sativa varieties. Physiology and Molecular Biology of Plants vol. 26 551-565 (2020).

163.Hozayn, M., Abd-Elmonem, A. A. \& Samaha, G. M. The physiological effect of presoaking with tryptophan on sugar beet (Beta vulgaris L.) productivity under different levels of salinity stresses. Bull. Natl. Res. Cent. 44, 0-8 (2020).

164.Chauhan, A. et al. Influence of gibberellic acid and different salt concentrations on germination percentage and physiological parameters of oat cultivars. Saudi J. Biol. Sci. 26, 1298-1304 (2019).

165.Shah, A. A., Ahmed, S., Abbas, M. \& Ahmad Yasin, N. Seed priming with 3epibrassinolide alleviates cadmium stress in Cucumis sativus through modulation of antioxidative system and gene expression. Sci. Hortic. (Amsterdam). 265, (2020).

166.Kalaivani, K., Kalaiselvi, M. M. \& Senthil-Nathan, S. Effect of methyl salicylate (MeSA), an elicitor on growth, physiology and pathology of resistant and susceptible rice varieties. Sci. Rep. 6, (2016).

167.Rizwan, M. et al. Zinc and iron oxide nanoparticles improved the plant growth and reduced the oxidative stress and cadmium concentration in wheat. Chemosphere 214, 269-277 (2019).

168.Shah, T. et al. Seed priming with titanium dioxide nanoparticles enhances seed vigor, leaf water status, and antioxidant enzyme activities in maize (Zea mays L.) under salinity stress. J. King Saud Univ. - Sci. (2020) doi:10.1016/j.jksus.2020.10.004.

169.Hacisalihoglu, G., Kantanka, S., Miller, N., Gustin, J. L. \& Mark Settles, A. Modulation of early maize seedling performance via priming under sub-optimal temperatures. PLoS One 13, (2018).

170.Kaymak, H. Ç., Güvenç, I., Yarali, F. \& Dönmez, M. F. The Effects of Bio-priming with PGPR on Germination of Radish (Raphanus sativus L.) Seeds under Saline Conditions. Turkish J. Agric. For. 33, 173-179 (2009).

171.Kabir, A. H. et al. Reduction of cadmium toxicity in wheat through plasma technology. PLoS One 14, (2019).

172.Migahid, M. M., Elghobashy, R. M., Bidak, L. M. \& Amin, A. W. Priming of Silybum marianum (L.) Gaertn seeds with $\mathrm{H} 2 \mathrm{O} 2$ and magnetic field ameliorates seawater stress. Heliyon 5, (2019). 